Federal Reserve Bank of New York

Staff Reports

\title{
Intended College Attendance: Evidence from an Experiment on College Returns and Costs
}

\author{
Zachary Bleemer \\ Basit Zafar
}

Staff Report No. 739

September 2015

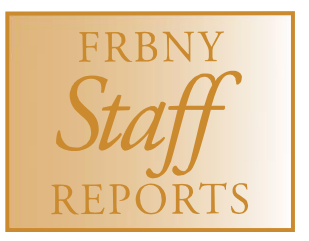

This paper presents preliminary findings and is being distributed to economists and other interested readers solely to stimulate discussion and elicit comments. The views expressed in this paper are those of the authors and do not necessarily reflect the position of the Federal Reserve Bank of New York or the Federal Reserve System. Any errors or omissions are the responsibility of the authors. 


\author{
Intended College Attendance: Evidence from an Experiment on College Returns and Costs \\ Zachary Bleemer and Basit Zafar \\ Federal Reserve Bank of New York Staff Reports, no. 739
}

September 2015

JEL classification: D81, D83, D84, I21, I24, I28

\begin{abstract}
Despite a robust college premium, college attendance rates in the United States have remained stagnant and exhibit a substantial socioeconomic gradient. We focus on information gapsspecifically, incomplete information about college benefits and costs - as a potential explanation for these patterns. For this purpose, we conduct an information experiment about college returns and costs embedded within a representative survey of U.S. household heads. We show that, at the baseline, perceptions of college costs and benefits are severely and systematically biased: 75 percent of our respondents underestimate college returns (defined as the average earnings of a college graduate relative to a non-college worker in the population), while 61 percent report net public college costs that exceed actual net costs. There is also substantial heterogeneity in beliefs, with evidence of larger biases among lower-income and non-college households. We also elicit respondents' intended likelihood of their pre-college-age children attending college, and the likelihood of respondents recommending college for a friend's child, the two main behavioral outcomes of interest. Respondents are then randomly exposed to one of two information treatments, which respectively provide objective information about "college returns" and "college costs." We find a significant impact on intended college attendance for individuals in the returns experiment: intended college attendance expectations increase by about 0.2 of the standard deviation in the baseline likelihood. Importantly, as a result of the college returns information intervention, gaps in intended college attendance by household income or parents' education persist but decline by 20 to 30 percent. Notably, the effect of information persists in the mediumterm, two months after the intervention. We find, however, no impact of the cost information treatment on college attendance expectations.
\end{abstract}

Key words: college enrollment, college returns and costs, information, subjective expectations

Bleemer: University of California Berkeley (e-mail: bleemer@ berkeley.edu).Zafar: Federal Reserve Bank of New York (e-mail: basit.zafar@ny.frb.org). This paper was previously circulated as "Information Heterogeneity and Intended College Enrollment." The authors have benefitted from comments made by participants at the Association for Education Finance and Policy 2014 spring meetings, Columbia Teachers College seminars, and Federal Reserve Bank of New York brown bag seminars. Any errors that remain are the responsibility of the authors. The views expressed in this paper are those of the authors and do not necessarily reflect the position of the Federal Reserve Bank of New York or the Federal Reserve System. 


\section{Introduction}

College enrollment rates, defined as the percent of high school graduates who have enrolled in a two- or four-year college, have hovered between 60 and 70 percent in the United States over the last two decades (National Center for Education Statistics (NCES), 2013). Over the same time period, the average college graduation rate in the US has been about 35 percent; that is, only about a third of young adults have gone on to complete a four-year college degree (OECD, 2013). As a result of this relative stagnancy in higher education enrollment and completion rates, the rate of growth of postsecondary education in the United States has been outpaced by OECD averages. ${ }^{1}$ Strikingly, these trends are not driven by a low or declining college premium over that period; in fact, the college premium appears to have been quite large and unchanged over this period (Oreopoulos and Petronijevic, 2013). Another notable and rather alarming fact is the large and persistent gap in college enrollment by both income and parental education (Bailey and Dynarski, 2011). There is a 30 percentage point gap in college enrollment by household income and by parents' educational attainment, which has remained relatively stable over time (National Science Board, 2014). ${ }^{2}$ Problematically, straightforward cost-benefit analysis would imply that these gaps should go in the opposite direction: college returns have been shown to be magnified for non-college households (Card, 1995), and government subsidies and private financial aid tend to make college costs lower for low-income households (Dynarski and Scott-Clayton, 2013).

In this paper, we focus on biased information about college costs and benefits as a possible explanation for these patterns. ${ }^{3}$ The idea is that households (especially disadvantaged households) may have incomplete and systematically biased information leading them to underestimate the benefits and overestimate the costs of college, which would then lead them to make suboptimal decisions. There are several reasons to believe that the role of information frictions may have increased in recent years. First, college net tuition has become increasingly

\footnotetext{
${ }^{1}$ While the gap between the United States and the OECD in high school graduation was essentially flat between 1995 and 2011 (moving from -8.3 percentage points - that is 8.3 percentage points higher rate in the US - to -5.1 percentage points), the gap in postsecondary entry rates as a fraction of high school graduates has narrowed more considerably, with the US outpacing OECD entry by 18.4 percentage points in 1995 but only by 12.2 percentage points in 2011 (OECD, 2013). The gap in college graduation has closed even more dramatically; US postsecondary graduation rates were 12.5 percentage points higher than the OECD average in 1995, but were 0.1 percentage points lower than the OECD by 2011 (OECD, 2013). See also Murnane (2013) for an overview of patterns in US high school graduation rates.

${ }^{2}$ In 2012, 81 percent of high school graduates in the United States' first income quintile had enrolled in college, compared to only 51 percent of high school graduates in the fifth income quintile (NCES, 2013). Likewise, in 2011, high school graduates who had at least one parent with a bachelor's degree had a 83 percent college enrollment rate, whereas high school graduates whose parents had no more than a high school degree had a 54 percent enrollment rate.

${ }^{3}$ There are certainly other possible explanations for these patterns. Rising college costs may have made more American households - in particular, lower-income and less-educated households - face severe credit constraints (Lochner and Monge-Naranjo, 2012), which might then leave them unable to invest in further education in the short-term despite the long-term benefits. Changes in students' college preparation and changes in resources at colleges over time could also partly explain the aggregate patterns as well as the gaps observed by socioeconomic background (Bound, Lovenheim, and Turner, 2010).
} 
individualized, with the gap between average sticker prices and average net prices increasing over the past 20 years, even for public schools, for which the gap increased from 26 percent to 45 percent between 1994 and 2013 (Baum and Ma, 2013). Second, while the average college premium remains stable, wage dispersion has increased substantially within educational categories as well as demographic groups (Autor, Katz and Kearney, 2008; Altonji, Kahn, and Speer, 2014). ${ }^{4}$ These suggest that information gaps have arguably played an increasing role in education trends over time (Scott-Clayton, 2012). Furthermore, given consistently and increasingly high levels of income and educational segregation in the US (Watson, 2009; Reardon and Bischoff, 2011) and the propensity of individuals to gather information from their local networks, disadvantaged households are more likely to have biased information about both college costs and benefits.

To examine the role of information gaps, we conduct two randomized information experiments, embedded within a survey, in which respondents are provided with objective information about either average college returns or costs. For this purpose, we added a novel set of questions to the January 2015 Survey of Consumer Expectations (SCE), a representative monthly survey of roughly 1,200 US household heads run by the Federal Reserve Bank of New York. At the baseline, respondents are asked about their perceived college costs and returns. ${ }^{5}$ Importantly, we make a distinction between perceptions of, say, college returns for the US population on average, and those for their own children or for the children of their friends. We refer to the former as "population" beliefs, since they pertain to perceptions of college benefits or costs for the US population on the whole, and to the latter as "self" beliefs, since they pertain to perceptions of college benefits or costs for the individuals' own children or those of their friends. This distinction is important because population beliefs measure an individual's stock of knowledge at a given point in time and can be directly validated, while self beliefs form the basis of the individual's own decision-making. Furthermore, a naïve comparison of self beliefs with actual statistics - an approach not uncommon in the prior literature - is ill-advised, because the two may not correspond for several reasons. For example, individuals may have private information about the child (such as ability and interests) that may justify having self beliefs that differ from actual statistics.

We elicit two measures of respondents' college attendance expectations. All respondents are asked for the expected likelihood with which they would recommend college attendance for a friend's child. Respondents with children under the age of 18 are also asked for the expected likelihood of their child attending college in the future. The advantage of eliciting intended behavior about an action that is yet to be undertaken is that we can investigate its

\footnotetext{
${ }^{4}$ The ratio of average annual earnings by college-educated and non-college-educated respondents to the Current Population Survey (CPS) has, however, remained largely stable, fluctuating between 1.78 and 1.83 from 2002 to 2012 .

${ }^{5}$ In this paper, we will refer to income differentials by education levels as "returns" to education. However, we do not mean to use this term to imply causal returns to schooling. As shown in Heckman, Lochner and Todd (2006), income differentials by education levels do not identify internal rates of return to investment in education.
} 
relationship with respondents' current stock of knowledge (as measured by their population beliefs), as well as measure how it changes in our information experiments. In addition, beliefs about intended behavior are also useful to study in themselves, since they tend to be strong predictors of actual future educational choices, above and beyond standard determinants of schooling (Jacob and Linkow, 2011; Beaman et al., 2012), and tend to be strongly associated with actual future outcomes (Dominitz, 1998; Delavande and Rohwedder, 2011).

In the intermediate stage, respondents are randomly assigned to either a control group or to one of two information treatments. In the first, which we refer to as the "returns" experiment, respondents are provided with the actual ratio of the average earnings of college graduates to those of non-college workers. ${ }^{6}$ In the second, the "cost" experiment, respondents are provided with the actual average net costs of both public and non-profit private universities. $^{7}$ The control group is provided with no additional information. In the final stage, we re-elicit self beliefs about college returns and costs, as well as the intended likelihood of the child attending college in the future, from all respondents. Finally, to investigate the longer-term impacts of information, we re-elicit both intended child's college attendance and population beliefs about college returns and costs from the same respondents in a follow-up survey two months later.

At the baseline, we find that nearly three-quarters of the respondents underestimate average returns to a college degree and more than 60 percent overestimate average college net costs. Moreover, both college-educated and higher-income respondents have significantly lower absolute errors in their perceptions about college returns, suggesting that biased beliefs about college returns may play a role in college attendance gaps by income and education. There are no notable disparities in population beliefs regarding net public college cost across education or income. In sum, while we find that household heads tend to underestimate net benefits and overestimate net costs of a college degree, the underestimation of net college benefits is both more prevalent overall and more extensive among disadvantaged respondents.

The mean expected probability that the child will attend college in our sample is 80 percent, with a standard deviation of 24 points, indicative of substantial heterogeneity in our sample. The heterogeneity in personal college attendance expectations is partly explained by individuals' locations: individuals living in higher-income areas, counties with higher actual relative college returns, and areas located near flagship public universities - all endogenous variables - have higher attendance expectations. We find a statistically and economically significant gap of between 10 and 15 points in child's intended college attendance expectations by parents' income or education status: for example, the mean likelihood of one's own child

\footnotetext{
${ }^{6}$ Throughout the paper, we use the term "non-college" to refer to individuals who do not have a 4-year bachelor's degree.

${ }^{7}$ We refer to objective statistics based on national-level datasets (such as the Current Population Survey) as "actual" or "true", when in fact they are just estimates based on (representative) samples of the population. However, this is after all the kind of objective information that individuals have access to when making related choices.
} 
attending college is 86 percent for higher-income households, versus 71 percent for their lower-income counterparts.

We also find that intended college attendance is strongly associated with subjective self beliefs about college returns for the child. This suggests that if self beliefs are causally based on perceptions regarding population college costs and returns, and if these population beliefs are systematically biased, then information interventions that provide objective information about college returns and other related aspects may impact intended choices. We test for this directly using our information experiments.

We find that the college returns intervention has an immediate positive impact on the reported likelihood of parents sending their child to college (an average increase of 5.1 percentage points) and on the likelihood of recommending college for their friend's child (average increase of 2.2 percentage points). This corresponds to an increase in child's college attendance expectations of 0.2 standard deviations. ${ }^{8}$ Furthermore, the impact is substantially larger for disadvantaged respondents. As a result, the education and income gaps in parents' expectations of their children's college attendance close by almost 30 percent (and the recommendation gaps close by 10 percent). For example, the income gap in the likelihood of child's college attendance shrinks by 6.5 percentage points. We show that the revisions are weakly positively associated with the informativeness of the signal, with respondents who underestimate the population relative college returns revising their beliefs about child's college attendance upward. This is consistent with respondents using the provided information to update their beliefs about skill prices (rather than the relative ability of the child). Finally, the impact of information on intended likelihood is found to be larger for respondents with greater revision in their beliefs about self college returns. This suggests that the intervention has an impact on respondent's college attendance beliefs in part by impacting their beliefs about the child's returns to a college degree.

A natural question to ask is whether the impact of the information persists beyond the horizon of the survey. The follow-up survey, conducted after two months, affirms the returns experiment's persistence (in the aggregate and at the individual level). College attendance expectations for treated respondents, on average, remain 3.4-5.6 percentage points higher than those of control group respondents (with the expectation gaps by income and education closing by as much as 40 percent for the groups treated with information).

The college cost intervention, on the other hand, is found to have no statistically significant impact on either measure of expected college attendance for the full sample or any of the demographic sub-groups. As a result, the college cost intervention has no significant

\footnotetext{
${ }^{8}$ Hoxby and Turner (2013) find that providing information on population net college costs and college application procedures to high-achieving low-income students increases students' enrollment in "peer institutions" by 0.12 standard deviations; Carroll and Sacerdote (2012) find that a combined information and fee-waiver intervention in New Hampshire public schools increases college enrollment by 0.11 standard deviations. The cost of these interventions varies drastically: $\$ 6$ per student for the former and around $\$ 600$ per student for the latter (Hoxby and Turner 2013). Note, however, that these are changes in actual enrollments rather than changes in the intended likelihood of enrollment.
} 
impact on the magnitude of the demographic gaps.

In sum, we find not only that an experiment informing a sample of US household heads of true average population college returns has a large and persistent impact on college attendance expectations, but also that its impact is larger and more persistent than a parallel experiment informing respondents of true average population college costs. The question of why the cost experiment does not lead to any significant impacts (at least in the short term) needs further research. It is, however, consistent with the literature's finding that people discount costs at a greater rate than they discount benefits (Loewenstein and Prelec, 1992; Abdellaoui, Attema, and Bleichrodt, 2010), which would result in a muted impact of the cost experiment.

In summarizing the population beliefs and self beliefs captured by our survey, and documenting the experimental link between the two, this paper contributes to the literature on people's stock of information about college returns and costs. However, existing works in this area either rely on small sample sizes or convenience samples, generally focus on either college costs or benefits (and not both), or rarely make a distinction between individuals' stock of knowledge (population beliefs) and beliefs as they pertain to the individuals themselves (self beliefs). Furthermore, most of the evidence is from the 1990s, and since then, both college costs and returns have increased. On the returns side, Smith and Powell (1990), Dominitz and Manski (1996), and Betts (1996) find that undergraduates' perceptions of the average college return are close to actual average college returns, while Avery and Kane (2004) find that high school students in the Boston area tend to substantially overestimate college returns. On the cost side, Horn, Chen, and Chapman (2003) find that the parents of high school students who intend to attend a 4-year college overestimate the average college net total costs by 11-26 percent; Avery and Kane (2004) find much larger overestimations for public school tuition (excluding room and board) among Boston high school students. They also find that more than 55 percent of both low-income and non-college parents of high school students report being not able to estimate college costs, far higher than their respective counterparts.

Our information experiment is also similar in spirit to information interventions conducted in the education literature. ${ }^{9}$ Our contribution, however, is to explicitly outline the mechanisms through which such interventions may have an impact, and to conduct two

\footnotetext{
${ }^{9}$ Wiswall and Zafar (2015a) find that students at a selective US university are misinformed about returns to college majors, and providing such information has an impact on intended major choice. Hoxby and Turner (2013) find that low-income high ability students in the US are responsive to information about net college costs in their choice of where to apply and enroll. Jensen (2010) and Nguyen (2008), in a developing country setting, find that students (or households) have poor information on returns to schooling and providing such information has an impact on educational attainment. Bettinger et al. (2012) and Dinkelman and Martinez (2014) find that providing information on financial aid improves certain educational outcomes. Oreopoulos and Dunn (2013) and McGuigan, McNally, and Wyness (2012) find that providing information about post-secondary education benefits to disadvantaged Toronto high school students and higher-income London 10th graders, respectively, has an impact on the students' expectations (regarding costs and benefits of post-secondary education) as well as on expected educational attainment.
} 
such interventions in an experimental setting. Our interventions are conducted on a large nationally-representative sample of American households, allowing us to examine broad average treatment effects that other studies, either due to small sample size or non-random sample selection, are unable to unbiasedly estimate. Moreover, these studies, with a few exceptions (Jensen, 2010; Wiswall and Zafar, 2015a, 2015b), do not collect data on baseline priors (regarding population costs or returns) and are usually unable to pin down the channels through which such interventions have an impact. ${ }^{10}$ Finally, we extend the literature by estimating not only the personal impact of information interventions on parents' expectations for the likelihood of their own child's college attendance, but also the social impact of non-targeted interventions on the likelihood of anyone recommending college for their friends' children.

This paper proceeds as follows. We describe the study design in the next section. Section 3 presents baseline beliefs: it first describes the accuracy of population beliefs, and then details the patterns in self beliefs and the relationship between population and self beliefs. Section 4 outlines the theoretical argument for why we may expect our information experiments to have an impact. Section 5 analyzes the results of our two experiments, and Section 6 concludes.

\section{Survey Design and Administration}

Our data are from a special module added to the Survey of Consumer Expectations (SCE), an original monthly survey fielded by the Federal Reserve Bank of New York. The SCE is a nationally representative, internet-based survey of a rotating panel of approximately 1,300 household heads. Respondents participate in the panel for up to twelve months, with a roughly equal number rotating in and out of the panel each month.

The monthly survey is conducted over the internet by the Demand Institute, a non-profit organization jointly operated by The Conference Board and Nielsen. The sampling frame for the SCE is based on that used for The Conference Board's Consumer Confidence Survey (CCS). Respondents to the CCS, itself based on a representative national sample drawn from mailing addresses, are invited to join the SCE internet panel. Each survey typically takes about fifteen to twenty minutes to complete. The response rate for first-time invitees hovers around 55 percent.

In January 2015, repeat panelists (that is, those who were not participating in the panel for the first time) were invited to participate in the special module. Out of a total sample of 1,387 household heads on the panel invited to participate in the survey, 1,146 did so

\footnotetext{
${ }^{10}$ For example, information interventions may have an impact on behavior if (1) the information was exante unknown, or (2) if the targeted individuals already had the information, but the intervention increases the salience of the information (Schwarz and Vaughn, 2002; Dellavigna, 2009). The two channels have different policy prescriptions.
} 
during January, implying a response rate of 82.6 percent. Two months later in March 2015, respondents who still remained in the SCE panel were invited to participate in a short followup module. Of the 993 household heads still in the panel, 814 did so, for a repeat response rate of 82 percent. The follow-up module was fielded between March 1 and 31. Respondents received $\$ 15$ for completing each survey.

\subsection{Survey Design}

We next summarize the design of the two surveys. We show the precise wording of each question in the empirical section, and provide the complete questionnaire in the appendix.

\subsubsection{First Survey}

The survey consisted of three stages.

Baseline stage: The first stage elicited respondents' perceptions regarding returns to a college degree and the costs of a college education, as well as beliefs regarding the child's college attendance. The data that we collected can be classified into three broad categories:

1. Population beliefs:

- Survey respondents were asked about the average earnings of current 40 year olds working full-time, with and without a college degree. We refer to these as "population earnings" beliefs.

- Survey respondents were asked about the average annual total net and sticker cost (including room, board, and tuition) of 4-year public as well as non-profit private universities. We refer to these as "population cost" beliefs.

2. Self child's beliefs:

- Survey respondents with children under age 18 in their household were asked about the likelihood of their oldest child's attending college, beliefs about the child's earnings at age 30 conditional on having or not having a college degree, and beliefs about the annual total cost of their child's college attendance.

3. Self friend's child's beliefs:

- Survey respondents were asked about the likelihood of their recommending a 4year college education for a hypothesized 15-year-old child of a friend who is currently in high school and performing well. Those without a child under age 18 were also asked for their beliefs about the friend's child's earnings at age 30 conditional on having or not having a college degree. 
Throughout the paper, we make a distinction between"self beliefs" on the one hand and "population beliefs" on the other. It is self beliefs that affect individuals' decisions, but it is hard to assess the accuracy of self beliefs since, by definition, the counterfactual states are not observed for the individual (we do not, for example, observe the earnings of a child both with and without a college degree). Furthermore, individuals may have private information about themselves which may, for instance, justify self beliefs about the child's earnings that are very different from population averages. The advantage of eliciting population beliefs, on the other hand, is that they reflect the individuals' present stock of knowledge, and we can directly assess their accuracy.

Intermediate stage: After eliciting the baseline set of beliefs, respondents are randomly assigned to one of three blocks (with an equal likelihood of being assigned to any of the blocks).

1. Respondents in the first block, which we refer to as the "college returns treatment", are first reminded of their population beliefs regarding college returns, and then receive objective information about college returns: "Analysis based on the 2012-2013 Current Population Survey shows that college-educated full-time workers in fact earn 1.80 times as much as non-college workers (that is, $80 \%$ more than non-college workers)."

2. Respondents in the second block, which we refer to as the "college costs treatment", are first reminded of their population beliefs regarding college costs, and then receive objective information about college costs: "According to the College Board Annual Surveys of Colleges, the average annual net cost of a 4-year public university in 20132014 was \$12,620, while that of a 4-year nonprofit private university was \$23,290."

3. Respondents in the third block, which we refer to as the "control group", are simply reminded of their population beliefs, and no objective information is revealed to them.

Final stage: Respondents assigned to either of the first two (treatment) blocks were next asked how useful and credible they found the presented information, and self beliefs about college returns and costs were re-elicited from them. Self beliefs about own and/or friend's child's college attendance expectations were also re-elicited from all respondents. This allows us to examine the effect of the information treatment on beliefs and expectations related to college attendance.

\subsubsection{Follow-Up}

In order to assess the persistence of the experimental effect in the medium-term, we followup with survey respondents two months later. We first re-elicit respondents' population beliefs about average earnings by college attendance and average university cost. We also 
elicit parents' expectations about their child's college attendance as well as all respondents' college attendance expectations regarding their friend's child.

Our study design is motivated by prior research that has found a close connection between self and population beliefs (Wiswall and Zafar, 2015a, 2015b). The idea is that if (1) individuals have biased population beliefs, (2) population and self beliefs are causally linked, and (3) decision-making is contingent on one's self beliefs, then information campaigns providing accurate information about population earnings and costs can affect self beliefs and thus decisions. In this paper, we do not present a formal model of the relationship between perceived public information and self beliefs; interested readers are instead referred to Wiswall and Zafar (2015b). Appendix B presents two stylized examples to illustrate why there might be a relationship, and to show that the direction of that relationship is ambiguous a priori.

\subsection{Other Data Sources}

We use several additional data sources in order to assess the accuracy of respondents' population beliefs, and to understand the correlates of the heterogeneity in these beliefs. In order to calculate the "true" (nation-wide) average earnings of college-educated and noncollege 40-year-olds, we compute the average full-time earnings of age 38-42 respondents in the 2012 and 2013 Current Population Survey (CPS). ${ }^{11}$ The College Board's 2013 Annual Survey of Colleges (Baum and Ma, 2013) provides a point estimate of the 2012-2013 enrollment-weighted average net tuition, fees, room and board for private and public universities. $^{12}$

In order to calculate local average earnings of college-educated and non-college 40-yearolds at the Public Use Microeconomic Area (PUMA) level, we use the 2012-2013 American Community Survey, made available through Minnesota Population Center's Integrated Public Use Microdata Series (IPUMS). ${ }^{13}$ We also derive local average public and private college sticker costs (at the state level, weighted by the enrollment of schools) using the 2012 Integrated Postsecondary Education Data System (IPEDS), maintained by the Department of Education's National Center for Education Statistics. ${ }^{14}$

These external data sources are also used to estimate several geographic demographic

\footnotetext{
${ }^{11}$ This aggregated sample of the CPS (over the twelve months in 2012) includes 13,815 respondents, though due to the sampling methodology of the CPS, some people appear in the dataset twice (in different months). It should be pointed out that we obtain similar statistics about relative college earnings (the object of interest in our analysis) when using the CPS data from the other years in the 2000s.

${ }^{12}$ College Board surveys 3,746 two- and four-year universities, with a response rate of 98 percent among public and non-profit universities and 38 percent for for-profit universities.

${ }^{13}$ PUMAs are the smallest geographic data available in the IPUMS census data. Each PUMA holds at least 100,000 people. PUMAs tend to follow county boundaries (without ever crossing state boundaries) and are larger than counties. There are 2,378 PUMAs in the United States. To calculate local 40-year-old average earnings, we average the earnings of individuals between the ages of 36 and 44 in order to preserve sample size.

${ }^{14}$ IPEDS includes total price information for 2,014 universities in its sample of 7,565 total universities in the United States.
} 
variables that are included in our analysis. We use the 2012-2013 ACS data to calculate both the fraction of adult residents in each PUMA who have at least a bachelor's degree and the median household income in each PUMA. Lastly, we use the IPEDS data to identify counties in which there is a "flagship" university (defined as one of the two largest four-year public universities in the state) and counties in which there is an "elite" university (defined as the 102 colleges and universities whose students' $75^{\text {th }}$ percentiles of reading and mathematics SAT scores are at least at the $90^{\text {th }}$ percentile of such scores in the US).

\subsection{Sample Statistics}

Of the 1,146 respondents, we drop 23 for whom we have missing data on any of the main variables used in the analysis. The first column of Table 1 shows the demographic characteristics of our sample. Our sample has respondents with higher income and higher educational attainment, and also has more white respondents, than the US population overall; 62 percent have annual household income greater than the $\$ 50,000$ US median, while 53 percent have bachelor's degrees and 83 percent are white. This may partly reflect differential internet access and computer literacy across various demographics. To make our sample representative, we use rim target weighting to match the targets for income, education, age, and region in the population. ${ }^{15}$ Column (2) of Table 1 shows that after weighting the sample, 48 percent of respondents are lower-income, 34 percent are college graduates, and 52 percent are male. The average age of the respondents is 51 years (with a standard deviation of 15), and 64 percent have high numeracy. ${ }^{16}$ Even after weighting the sample, 82 percent of respondents are white, suggesting that we somewhat over-sample that population. All analysis reported in the paper uses sample weights, though results are qualitatively similar without them.

Column (2) also shows other household characteristics of our weighted sample. More than a quarter of respondents have children under 18 years old, and 9 percent have children between the ages of 14 and 17 in their household. On average, respondents live in areas in which 30 percent of adults are college graduates and in which the median income is $\$ 58,900$. 16 percent of respondents live in the same county as a "flagship" university, and 22 percent of respondents live in the same county as an "elite" university.

Table 1 also sub-divides the sample by the three experimental groups: the control group, those who participated in the returns experiment, and those who participated in the cost experiment. Due to respondents' random assignment into these three groups, we unsurprisingly find no evidence of systematic differences in any of the summary statistics by group

\footnotetext{
${ }^{15}$ The sources of the targets are as follows: for income, we use the Annual Social and Economic Supplement (ASEC) of the 2010 Current Population Survey. For education, we use the 2010 American Community Survey. For age, we use the 2010 Census data for household heads, combined with estimates of total population by age. For region, we use the 2011 Census Bureau state-level population estimates.

${ }^{16}$ Our survey included a battery of 5 numeracy questions. The numeracy questions were drawn from Lipkus, Samsa, and Rimer (2001) and Lusardi (2009). We code respondents answering at least 4 of the 5 questions correctly as "high numeracy".
} 
at the five percent level (as indicated by the p-values in column 6 for the equality of means across the three groups).

Finally, column (7) of Table 1 shows the unweighted demographic statistics of the 814 respondents to the March follow-up survey. 51 percent of the attrition (168 respondents) can be explained by structural rotation out of the SCE panel, which occurs after 12 months, with the rest of the attrition due to non-response. Column (7) shows that the March sample is slightly older and less likely to have young children than the full sample, but that the two samples are otherwise similar. Appendix Table A1 presents estimates of a multivariate linear regression of a dummy variable for whether an eligible respondent participates in the follow-up. With the exception of age and having a child under the age of 18, none of the variables are statistically significant at the five percent level.

\section{Descriptive Analysis}

\subsection{Population Beliefs}

Earnings Beliefs: Survey respondents were asked for their beliefs of average earnings of college and non-college workers. ${ }^{17}$ The first two rows in Table 2 show that the average population non-college and college earnings beliefs in our sample are $\$ 35,900$ and $\$ 57,500$, respectively. ${ }^{18}$ College-educated and higher-income respondents report significantly higher beliefs than their counterparts. The third row in the table reports the ratio of these two beliefs, which we refer to as the population relative college earnings (RCE). The mean in the sample is 1.63; that is, on average, respondents believe that current 40 year old collegegraduate workers earn 1.63 times more than non-college workers. The average population $\mathrm{RCE}$ is significantly higher for college-educated respondents than for non-college respondents (1.67 versus 1.61). There is no statistical difference in the population RCE conditional on respondents' household income.

One of the purposes of eliciting respondents' population beliefs is to gauge their accuracy compared to objective statistics (we refer to these statistics as the "true" values occasionally, when in fact they are just estimates from a sample). For this, we use earnings information of 38-42 year old full-time workers from the 2012-2013 Current Population Survey (CPS), pooling across the months. The data reveal that, in 2012, average earnings of full-time college-graduate workers were $\$ 75,500$, while those of non-college workers were $\$ 42,200$. Comparing these numbers with respondents' population earnings beliefs, we see

\footnotetext{
${ }^{17}$ For example, population beliefs about earnings of non-college workers were elicited as follows: "Consider all non-college individuals (that is, individuals without a Bachelor's degree) currently aged 40 who are working full time right now. What do you believe is the average amount that these workers currently earn per year, before taxes and other deductions?"

${ }^{18}$ In order to limit the impact of outliers on the results presented in this paper, we winsorize our dataset by experimental block at the top and bottom 2.5 percent of each variable of interest.
} 
that our respondents, on average, underestimate earnings of college-graduate workers by about $\$ 18,000$ (24 percent), and those of non-college workers by about $\$ 6,300$ (15 percent). Notably, every sub-group that we consider in Table 2 underestimates earnings of both college and non-college workers.

The actual population RCE, based on the 2012-2013 CPS data, is 1.80. In fact, the RCE has been between 1.76 and 1.83 since 2000, suggesting little change in relative earnings of college workers over the last decade. We see that 75 percent of our respondents, uniformly across education and income groups, underestimate the RCE. The last row in Panel A of Table 2 reports the absolute error in the RCE, that is, the absolute value of the perceived population RCE minus true population RCE. The large mean absolute error of 0.41 , far higher than the mean error of 0.17 , indicates that a non-trivial proportion of respondents makes both positive and negative errors. However, college-educated and higher-income respondents have lower mean absolute population RCE error than their counterparts.

The first two columns of Appendix Table A2 show correlates of heterogeneity in the population RCE beliefs and the absolute error in population RCE beliefs. Female, high-numeracy, and white respondents tend to hold higher population RCE beliefs, while individuals who live in high-income areas tend to have slightly lower population RCE beliefs. Interestingly, respondents who reside in areas with a high actual RCE do not have measurably higher RCE beliefs than those in lower RCE areas. Column 2 of the table shows that, even conditional on these other demographic characteristics, lower-income and non-college respondents tend to have higher average absolute errors in their population RCE beliefs than their counterparts.

Figure 1 shows the distribution of the perceived population RCE in our sample. If respondents were fully informed about relative college returns, the distribution would have been concentrated around the true value of 1.80. We see that is not the case. Furthermore, the distribution is not symmetric around the true value (as would be the case if there were classical measurement error in the survey data), but is right-skewed, with 75 percent of the respondents underestimating the population RCE.

Cost Beliefs: We next turn to respondents' beliefs about college costs. Respondents were asked for the sticker as well as net cost of both public and private universities. ${ }^{19}$

Panel B of Table 2 shows that, on average, respondents believe that the average annual sticker (net) cost (including room, board, and tuition) of a 4-year Bachelor's degree at a public college is $\$ 30,600(\$ 23,400)$, while at a private college is $\$ 43,400(\$ 35,300)$. Higher-income and college-educated respondents tend to have higher beliefs about nonprofit private college costs, but there is little variation in public college perceived costs by either respondents'

\footnotetext{
${ }^{19}$ The net cost, for example, was elicited as follows: "Many students who go to college quality for grants and scholarships (money that students get that they don't have to work for or pay back), and as a result end up paying less than the sticker cost. This cost of college after taking into account grants and scholarships is referred to as the net college cost. This is the amount that students actually have to pay. What is your best guess of the current average annual net cost of a 4-year Bachelor's degree at a [public / nonprofit private] university?"
} 
education or income.

A natural question to ask is how do respondents' perceived college costs compare with actual costs. According to analysis by the College Board, the average annual net cost (including tuition, fees, room, and board) at a 4 -year public college was $\$ 12,600$ for the 2013-2014 school year, while the average annual sticker price was $\$ 18,400$. Similarly, the average annual net cost at a 4-year private college was $\$ 23,300$ for the 2013-2014 school year, and the average annual sticker price was $\$ 40,900$.

Figure 2 shows the distribution of population beliefs about college costs. Respondents' beliefs about net public and private college costs are concentrated around the true values, but the distributions are non-centered and right-skewed; 61 percent of respondents overestimate each net cost. Public sticker cost beliefs are concentrated around the true cost and roughly centered, with only 46 percent of respondents overestimating true public sticker costs, while private sticker cost beliefs are more varied.

In all four cost categories, respondents in every demographic group hold average population cost beliefs that overestimate actual college costs. For example, respondents' average estimate of net public college costs are almost double the actual average $(\$ 23,400$ vs. $\$ 12,600)$, and 61 percent of respondents overestimate average total net public college costs. Average private college sticker costs are only overestimated on average by $\$ 2,500$. There is, however, substantial heterogeneity in college cost beliefs; for example, the standard deviation of sticker public college cost beliefs is $\$ 22,000$. The last two columns of Appendix Table A2 show that this heterogeneity is not explained by either education or income: column (3) of the table, for example, shows that only about 4 percent of the variation in population sticker cost beliefs for public universities is explained by our full suite of demographic information.

The analysis so far reveals both substantial heterogeneity in respondents' population beliefs and substantial errors in their perceptions. Moreover, the biases in population beliefs are systematic, with respondents more likely to underestimate the population RCE and generally more likely to overestimate college costs (the only exception being the sticker cost of private college, which is overestimated by less than half of the sample). Notably, the heterogeneity in population beliefs is largely unexplained by our rich set of covariates. To what extent are our conclusions driven by respondents using local information to report their perceptions? In order to assess the role of geographic variation in these measures driving our conclusions, we instead evaluate the accuracy of our respondents' population beliefs by comparing them to local benchmarks; for the population RCE, we compare their beliefs with the actual population RCE in the respondent's PUMA, while for college costs we compare respondents' perceptions with a weighted average of 2012 sticker college costs in the respondent's state of residence. We find that the average population RCE error is statistically indistinguishable from the average population RCE local error (0.172 vs. 0.189), and that average population RCE absolute error is actually significantly lower than average population RCE local absolute error (0.41 vs. 0.50). However, we do find that average 
population public college sticker cost error is substantially smaller when compared to local public college costs ( $\$ 12,300$ national error vs. $\$ 7,000$ local error), though in absolute terms the average errors are very close $(\$ 17,300$ national vs. $\$ 16,500$ local $)$; the same pattern holds for private college sticker cost error. These results suggest that geographic variation in actual college returns and costs can explain a very small part of the underlying heterogeneity in respondents' population beliefs.

\subsection{Self Beliefs}

We next turn to analysis of respondents' self beliefs: that is, their beliefs about their oldest child below age 18 (pre-college age) and about the hypothetical 15-year-old child of a friend. First, survey respondents were asked about their oldest child's expected earnings at age 30 conditional on their earning - or not earning - a college degree, their child's expected annual total net college cost, and the likelihood of the child attending college. In our sample, 310 respondents reported beliefs for a pre-college age child. We then ask all respondents for the likelihood of them recommending to a friend that their 15-year-old child go to college, if that child was currently in high school and performing well. ${ }^{20}$ Finally, we ask respondents who do not have children under the age of 18 for the expected earnings of that friend's 15-year-old child at age 30, conditional on their either earning or not earning a college degree.

As above, we calculate the self child's and friend's child's RCE as the ratio of expected earnings with a bachelor's degree to expected earnings without a bachelor's degree. These self RCE calculations differ from the population calculations in two ways. First, they are calculated as projections about the future, when the population RCE may be higher or lower than it is presently. Second, they are estimated given private knowledge about the characteristics of one's own child (or one's friends) which may influence respondents' expectations about their future earnings. Thus, respondents who report own child's and friend's child's RCE beliefs that are greater than their population RCE beliefs may believe that the population RCE is increasing over time, or may believe that their (or their friend's) child will earn a higher premium than the average.

Earnings Beliefs: Panel $\mathrm{C}$ of Table 2 shows that the average child's RCE belief in our sample is 1.78, while the average friend's child's RCE belief is 1.58. Respondents' own child's RCE beliefs are, on average, significantly higher than their population beliefs, while respondents' friend's child's RCE beliefs are significantly lower than their population beliefs (at the 10 percent level). College-educated respondents tend to have, on average, higher friend's child's RCEs than non-college respondents, but there is otherwise no discernible heterogeneity across income and education subgroups despite substantial variation in both

\footnotetext{
${ }^{20}$ The question was: "A friend of yours has sought your advice about whether to send their 15-year old child to college for a 4-year degree. The child is currently in high school and performing well. What is the percent chance that you would recommend a college education for the child to your friend?"
} 
RCE beliefs (a standard deviation of 0.56 for child's RCE and 0.45 for friend's child's RCE).

Cost Beliefs: Panel C also shows respondents' expected child's net college costs, which average $\$ 25,500$. This expected cost is more than double than the actual average public school net cost. Surprisingly, higher-income respondents' expected costs are only slightly (and statistically insignificantly) larger than those of lower-income respondents, despite lowerincome households typically facing far lower net college costs than higher-income households (Dynarski and Scott-Clayton, 2013).

College Attendance Beliefs: Finally, Panel C shows that the mean probability that the child will attend college is 80.2 percent, with substantial heterogeneity in the belief (a standard deviation of 24 points). Notably, we see that college-educated respondents report a significantly higher average likelihood of their pre-college age child attending college (87 percent versus 76 percent for non-college respondents). Likewise, higher-income respondents report a significantly higher mean likelihood of their child attending college (86 percent versus 71 percent for their lower-income counterparts). These differences are statistically significant at the 1 percent level. Similarly, the average likelihood of an individual recommending college for a friend's child is 81.5 percent, and college-educated and higher-income respondents report significantly higher likelihoods than their counterparts (at the 1 percent level). ${ }^{21}$

Note that the mapping of intentions to actions does not have to be one-to-one. That the average likelihood of college attendance for one's own child is, say, 86 percent for higherincome respondents does not, in any way, mean that 86 percent of children from higherincome households will enroll in college. Likewise, the gap in expectations of, say, 15 percentage points in a child's college attendance by household income does not have to mirror the actual gap in college enrollment by income. ${ }^{22}$ For intended actions and expectations to be of interest, the only relevant factor is that they be causally relevant for future actions. Indeed, we know from a growing literature that expectations tend to be strong predictors of educational choices, above and beyond other standard determinants of schooling (Jacob and Linkow, 2011; Beaman et al., 2012). Likewise, several studies show that schooling choices can be explained by ex-ante expectations (Attanasio and Kauffmann, 2012; Stinebrickner and Stinebrickner, 2014; Wiswall and Zafar, 2015a).

\footnotetext{
${ }^{21}$ Columns (1) to (4) of Appendix Table A3 show the demographic heterogeneity in college attendance expectations for one's own child. Even after including an exhaustive set of controls, lower-income respondents are substantially and significantly less likely to expect to send their children to college. Individuals who live near flagship state universities or in higher income areas report significantly higher likelihood of sending their children to college, while individuals who live in states with high average private university sticker prices are less likely to expect their child to attend college. Columns (5) to (8) of Appendix Table A3 show that both lower-income and non-college respondents are far less likely to recommend college for their friend's child.

${ }^{22}$ In fact, the enrollment rate of recent high school graduates (largely 18 year olds) was 68.2 percent in 2011 (and has oscillated in a narrow range of 61.8-70.1 percent over the last 2 decades), with an enrollment rate of 82.4 percent for youth from higher-income households and 53.5 percent from low-income households (National Science Board, 2014; low (high) income is defined as being in the bottom (top) 20 percent of the US income distribution).
} 


\section{Theoretical Motivation}

We next introduce some notation that is useful for motivating the experimental analysis.

\subsection{Self Beliefs and Population Beliefs}

Let $R C E_{i t}^{\text {child }}$ be individual $i$ 's expectation at time $t$ about the child's future RCE (child here may refer to one's own child or a friend's child). Let $\Omega_{i t}$ denote $i$ 's information set at time $t$, and $X_{i}$ a vector of demographic characteristics. Respondent $i$ reports her beliefs about the child's RCE as:

$$
R C E_{i t}^{\text {child }}=E\left(\mathbf{R C E}_{\mathbf{c}} \mid \Omega_{i t}\right)=f_{c}\left(\mathbf{X}_{\mathbf{i}}, \Omega_{i t}\right)
$$

The function $f_{c}(\cdot)$ maps the individual's demographic characteristics and information set to self beliefs. We take a broad view of the individual's information set. The individual's information set $\Omega_{i t}$ may contain both self (private) information, such as the individual's perceived ability of the child, and population information, such as the individual's perception of average relative earnings for workers with a college education (that is, $R C E_{i t}^{p o p}$ ). Note that we allow for the possibility that respondents' perceptions about the population distribution could be different from the actual measures. Hence, the information set about the population distribution of earnings could vary over time and across individuals.

In the information experiments that we discuss in Section 5, we will test whether, and to what extent, individuals' expectations of their child's RCE depends in some way on their perceived population RCE, that is, whether $\frac{f_{c}\left(\mathbf{X}_{\mathbf{i}}, \Omega_{i t}\right)}{\partial R C E_{i t}^{\text {pop }}} \neq 0$. First, however, we analyze whether individuals' self beliefs are systematically related with their population beliefs. In column (1) of Table 3, we regress the child's RCE onto our suite of demographic controls as well as the respondents' population RCE belief. The estimate on the population RCE indicates that perceived population RCE is economically and statistically significantly related to beliefs about the child's RCE. A 0.17 increase in beliefs about the population RCE (that is, the average amount by which our sample underestimates the population RCE) is associated with an increase in beliefs about one's own child's RCE by 0.11 points. Column (2) of Table 3 shows a similar, though somewhat smaller, relationship between population RCE beliefs and friend's child's RCE beliefs.

Columns (3) and (4) of Table 3 examine the relationship between population cost beliefs and self child's cost beliefs. We find that, of the four population cost beliefs discussed above (sticker and net costs for public and nonprofit private universities), the strongest association exists between average public net cost beliefs and self child's cost beliefs, with a $\$ 10,000$ increase in population net cost beliefs being associated with a $\$ 4,000-\$ 5,000$ increase in expected child's net college costs. We focus on the relationship between public net cost beliefs and self child's cost beliefs in our experimental analysis below. 
In short, Table 3 shows a strong relationship between self and population beliefs.

\subsection{Intended Colllege Attendance and Beliefs}

A respondent's reported likelihood at time $t$ of the child's college attendance, denoted by College ${ }_{i t}^{\text {child }}$, is a function of the respondent's information set, $\Omega_{i t}$, and $\mathbf{X}_{\mathbf{i}}$, a vector of demographic characteristics. As before, the information set may contain private information about the child, such as the expected returns to a college education for the child (that is, the child's RCE), as well as population information, such as the perceived costs of a college education.

Table 4 estimates the relationship between child's college attendance and both population and self beliefs about the returns and costs of college attendance. The dependent variable in columns (1)-(3) is own child's intended college attendance. In column (1), we see that respondents with higher population RCE beliefs also tend to be slightly more likely to expect their child to attend college: an increase in population RCE beliefs of 0.17 is associated with a 1 percentage point increase in the likelihood of child's college attendance. There is no significant relationship between population college cost beliefs and child's college attendance. Interestingly, column (2) shows that individuals who expect higher college costs for their children are more likely to send them to college, perhaps reflecting the aid structure of college costs, which are higher for higher-income households (though the regression controls for these demographics). We find a positive relationship between child's RCE beliefs and expected child's college attendance, but it is statistically insignificant. Nevertheless, in total these results suggest that individuals with higher RCE beliefs tend to have higher child's college attendance expectations.

Columns (4) to (6) of Table 4 show the relationship between friend's child's college attendance expectation and both population and self beliefs about college. As in the case of own child's intended attendance, the relationship between college attendance and both population and self friend's child's RCE beliefs is positive. The estimate on the child's RCE is both substantially and significantly larger than the relationship for one's own child; an increase in friend's child's RCE beliefs of 0.17 is associated with an increase in the child's college attendance expectation of over 2.5 percentage points. Again, however, population college costs are unrelated to college attendance.

We have shown that household heads, on average, underestimate population relative college earnings (RCE) and overestimate public and nonprofit private college net costs. Respondents' self beliefs about their (own or friend's) child's RCE and college costs are shown to be related to their population beliefs (Table 3), and these self beliefs are important correlates of the child's college attendance likelihood (Table 4). If these relationships are in anyway causal, then these misinformed population beliefs may systematically bias self beliefs, and adversely affect the likelihood of the child's intended college attendance. We investigate this 
in the next section.

\section{Experimental Analysis}

This section present results from two experiments. In the first, the returns experiment, we provide respondents with the actual population $\mathrm{RCE}$, while in the second, the cost experiment, we provide respondents with the actual average total net cost of public and private universities. In both experiments, we examine the effect of this information on individuals' self beliefs, focusing in particular on their expectations for their (own and friend's) child's college attendance. We also examine changes in their self RCE and college cost beliefs, which could be one possible channel through which updated population beliefs about college returns and costs affect self college attendance beliefs.

Panel A of Table 5 shows the baseline beliefs. The first row, which summarizes own child's college attendance expectations, displays averages for only the restricted sample of respondents with children under age 18. The second row, summarizing friend's child's college attendance expectations, covers the full sample. As discussed above, respondents' average college attendance expectation for their own child and friend's child is similar: 80.2 and 81.5 percent, respectively. College-educated and high-income respondents have higher college attendance likelihoods, with average gaps of 11.3-14.9 percentage points compared to their counterparts. Panel B shows that college attendance expectations changed minimally for the control group, with no statistically significant changes at the five percent level. We do see a small 0.9 average increase (significant at the 10 percent level) in the likelihood of own child's college attendance. This should not be entirely surprising since the mere act of taking a survey may prompt respondents to think more carefully about their responses, and may lead them to revise their beliefs between the initial and intermediate stages (see Zwane et al., 2011, for a discussion of how surveying people may change their subsequent behavior). The purpose of including a control group in the study design is precisely to purge these confounding effects from the treatment groups' revisions.

\subsection{Returns Experiment}

Immediate Impact: Panel $\mathrm{C}$ of Table 5 displays the average (immediate) change in college attendance expectations for the returns experiment. ${ }^{23}$ We find that own child's intended college attendance expectations, on average, increase by 5.1 percentage points. This represents a 7 percent increase in respondents' expected likelihood of sending their child to college. More-

\footnotetext{
${ }^{23}$ Because only one-third of respondents were randomly selected to participate in the returns experiment, Panel A does not necessarily provide a proper baseline comparison (since baseline college attendance beliefs may differ between these participants and all respondents). For this reason, we display post-information changes in beliefs instead of merely post-information beliefs.
} 
over, we find that non-college and lower-income respondents revise their beliefs to a greater extent than their privileged counterparts, which leads to a decline in the college attendance expectations gap by socioeconomic status (by education and income, as shown in columns 4 and 7 of Table 7 , respectively). Non-college respondents revise their expected attendance likelihood up by 6.5 percentage points, compared to 3 percentage points for college-educated respondents, which implies that the college gap shrinks by 27 percent; lower-income respondents revise their expected attendance up by 8.8 percentage points, compared to 2.3 percentage points among higher-income respondents, shrinking the income gap in intended college attendance by 21 percent. We find a similar positive impact on friend's child's intended college attendance, which increases by 2.2 percentage points. Again, the impact is larger for non-college and lower-income respondents, as a result of which the college and income gaps in intended college attendance both decrease by about 10 percent. ${ }^{24}$

Table 6 presents the results in a regression framework. The dependent variable is the change in expected college attendance (final minus baseline). We now include all respondents, including those in the control group (who were provided no new information, but were reminded of their own population RCE and cost beliefs). This allows us to purge the revisions attributable to the act of taking the survey and to identify the causal effects of the information. Controlling for our suite of demographic covariates, column (1) shows that respondents in the returns experiment, on average, revise their own child's college attendance expectations upwards by 4.5 percentage points.

Column (2) includes an additional variable, "Pop. RCE Error", which is simply the subjective minus actual RCE (so a positive number indicates overestimation of the population $\mathrm{RCE}$ ). If individuals revise their beliefs in a manner that is proportional to the informativeness of the provided information, which is captured by this term, we expect the coefficient to be statistically different from zero. The estimate is not precisely estimated but is sizable and negative, indicating that respondents who (under-) over-estimate the population RCE revise (up) down the intended college attendance of their child. This would be consistent with respondents primarily responding to the skill prices information embedded in the signal. Columns (5) and (6) of Table 6 show that the same qualitative patterns hold for friend's child's college attendance expectations. Appendix Table A4 show that the largest increase in both measures of college attendance expectations is exhibited by low-income non-college respondents.

\footnotetext{
${ }^{24}$ All results presented in this section are weighted using the sample weights described above. However, all presented results are robust to the exclusion of these weights. Unweighted individuals treated with rewards information are 3.7 percentage points more likely to send their children to school and 1.7 percent more likely to recommend college for a friend's child, both significant at the 1 percent level. All four demographic groups experience significant increases in both measures of expected college attendance, and three of the four demographic gaps experience significant declines (the 1.8 percentage point decline in the income gap of expected own child's college attendance is large but statistically insignificant). We also corroborate the medium-term effects presented below; the effects on the unweighted sample are nearly identical to those on the weighted sample in sign, magnitude, and statistical significance.
} 
One concern for information experiments is the degree of credibility assigned to the provided information. In the returns experiment, we inform respondents that the information presented comes from a survey "jointly sponsored by the US Bureau of Labor Statistics and the Census Bureau." On a credibility scale from 1 to 5 , where 1 is "absolutely not credible/useful" and 5 is "absolutely credible/useful", 57 percent of respondents rated the information's credibility 4 or 5 (which we consider finding the information credible), with another 29 percent rating its credibility $3{ }^{25}$ Column (3) of Table 6 shows that the respondents who found the information credible had larger positive revisions for their own child's college attendance expectations, though the estimate is not precise. Column (7) reports the corresponding estimates for friend's child's college attendance expectations, where the larger sample size contributes to the coefficient's precise estimation: respondents who did not find the information credible upwardly revised their likelihood of recommendation by 1.1 percentage points on average, while those who did find it credible revised their likelihood up by almost 3 percentage points.

Columns (4) and (8) of Table 6 examine the proposed channel through which population RCE information leads to revisions of college attendance expectations. The two columns interact experimental participation with the (final minus baseline) change in the child's expected RCE. If revisions in child's RCE are a channel through which respondents are revising the intended likelihood of the child's college attendance, we expect this term to be positive and statistically significant. That is in fact what we find: respondents who, for example, increase their child's RCE by 0.1 points have a 0.73 point higher increase in the likelihood of their child attending college. Notably, we see that the indicator for the returns experiment retains a large and highly statistically significant relationship with college attendance expectations, implying that this proposed mechanism only partially explains the relationship between population beliefs and expected college attendance. The continued significance of the indicator for the returns experiment could be consistent with respondents revising the college attendance beliefs as a result of the salience of the provided information (Dellavigna, 2009).

Medium-term Impact: So far, our presented experimental results have been measured immediately after respondents received the returns information treatment. A natural question to ask is whether these belief changes persist over time. Our follow-up survey allows us to look at this.

Panel $\mathrm{C}$ of Table 7 summarizes the impact of receiving the information treatment in January on college attendance expectations in March, two months later. Due to sample size constraints, we restrict our analysis to friend's child's college attendance expectations,

\footnotetext{
${ }^{25}$ College-educated respondents were more likely to report finding the information credible. Respondents with higher population returns beliefs were also more likely to find the information credible, suggesting that those whose beliefs conformed more closely to the information were more likely to believe it. Results are available from the authors upon request.
} 
though our findings for own child's expectations $(\mathrm{N}=63)$ are qualitatively similar. We find that our results persist strongly in the medium-term. Respondents increased their friend's child's college attendance expectations by 3.4 percentage points (compared to the control group's 0.2 percentage point decline), a somewhat larger revision than in the January initial survey. The increase is largely driven by lower-income respondents, and the income gap in intended college attendance expectations closed by almost half (7.7 percentage points), a statistically significant change at the 5 percent level. The education gap also closed, though the 2.2 percentage point change was statistically insignificant.

Regression analysis, available from the authors, shows that the effect of the rewards experiment is (1) large and statistically significant, and (2) persistent at the individual level. Controlling for demographics, a one percentage point January increase in college attendance expectations implies a (statistically-significant) 0.88 percentage point increase in March, suggesting remarkable persistence in the impact of information on beliefs.

\subsection{Cost Experiment}

Immediate Impact: We next turn to the cost experiment, findings of which are summarized in Panel $\mathrm{C}$ of Table 5. We find no evidence that respondents in the cost experiment revise either their child's expected likelihood of college attendance or the likelihood of their recommending college attendance for a friend's child, on average. In fact, we find no evidence of the experiment changing the college attendance expectations for any of the four demographic groups that we examine (Appendix Table A4). As a result, there is no significant impact on expectations gaps by income or education. ${ }^{26}$

Table 6 provides more nuanced evidence of the cost experiment's failure to change respondents' college attendance expectations. Column (1) shows that the cost experiment appears to have had no statistically significant impact on child's college attendance expectations (and, if anything, may have lowered those expectations). Controlling for the respondent's population public cost error in column (2) has little impact. Column (4) shows that respondents who revise up (down) their beliefs about college costs also revise up (down) their child's expected college attendance. ${ }^{27}$ The lack of an impact of the cost experiment on intended college attendance is particularly notable since we find that the effect of the cost experiment on self net cost beliefs is quite dramatic, with respondents revising their child's expected net costs downwards by more than $\$ 9,000$ on average (see columns 7-9 in Appendix Table A5).

Credibility plays an important role in the impact of the cost experiment on expected

\footnotetext{
${ }^{26}$ As in the rewards experiment, we find highly similar effects on the unweighted sample; the impact of the cost experiment is small and statistically insignificant in the short- and medium-term: for the likelihood of recommending college for a friend's child, for example, the treatment effects are 0.2 percentage points and 0.6 percentage points, respectively.

${ }^{27}$ Though we only discuss average public net cost in our analysis of the cost experiment, the results are qualitatively similar for average private net cost.
} 
college attendance. The cost experiment presents information "according to the College Board," which many respondents likely recognized as the nonprofit corporation that facilitates the popular SAT college examination. Respondents' distribution of credibility was very similar to that of respondents in the returns experiment: 62 percent of respondents found the information credible (rating the information's credibility 4 or 5 out of 5), with another 23 percent rating its credibility 3 . As in the returns experiment, people with more accurate population net public college costs found the information more credible. Column (3) of Table 6 shows that respondents who found the information credible maintained almost-unchanged personal college attendance expectations, while the negative effect of the cost information treatment was driven by individuals who did not find the information to be credible; among the latter population, own child's college attendance expectations declined by almost 6 percentage points on average, statistically significant at the 10 percent level. This pattern, unobserved in the returns experiment (in which credibility strengthened the experiment's positive impact), similarly manifests in column (7), which tests the effect of the cost experiment on friend's child's college attendance expectations; the likelihood increases slightly for respondents who find the information credible and decreases slightly for those who don't (with a statistically significant difference between the two). Interestingly, credibility does not seem to substantially mediate the decline in self net cost beliefs; those who do not find the information credible revise their net cost beliefs downward by about $\$ 8,700$, while those who do find it credible revise down by $\$ 9,700$, where the difference is not statistically significant (see Appendix Table A5).

Medium-term Impact: Panel D of Table 7 summarizes the medium-term impact of the cost experiment, again restricting our analysis to friend's child's college attendance expectations due to sample size constraints. As in the initial survey, we find no measurable impact of participation on expectations; expectations increase by an average of 0.8 percentage points (standard error of 1.4), relative to a control group decline of 0.2 percentage points. Only higher-income respondents experience a statistically-significant increase in expectations, by 2.6 percentage points. Regression analysis, available from the authors, confirms these conclusions; even conditional on demographic characteristics, we find no evidence of the cost treatment having any persistent effects on expectations.

\section{Conclusion}

Nearly a third of high school graduates in the US do not enroll in college. In fact, for children whose households are in the lowest quintile of the US income distribution, nearly half of high school graduates do not enroll in college. Given the robust and high return associated with a college degree, as well as college tuition subsidies for lower-income households, these patterns 
continue to puzzle researchers and policy-makers alike. ${ }^{28}$ This paper focuses on information constraints as one possible explanation for these patterns.

We report results from two randomized information experiments. In the first, respondents are informed that college-educated workers' annual earnings are 80 percent higher than those of non-college workers (see Jensen, 2010, and Nguyen, 2008, for international examples). In the second experiment, respondents are informed that the average annual net costs of public and non-profit private universities in the US are $\$ 12,620$ and $\$ 23,290$, respectively (among examples of cost-based interventions conducted in the US are Carroll and Sacerdote, 2012, and Hoxby and Turner, 2013). We elicit respondents' beliefs regarding their (own and/or friend's child's) college attendance and other related outcomes, before and immediately after the information intervention, as well as two months later.

At every stage of our analysis, we find that respondents are more susceptible and reactive to college returns information than to college cost information. At the baseline, household heads tend to underestimate net benefits and overestimate net costs of a college degree. The underestimation of net college benefits is greater among disadvantaged respondents. We find that the college returns intervention has an immediate positive impact on the likelihood of parents sending their child to college and on the likelihood of respondents recommending college for their friend's child, and has substantially larger impacts on non-privileged respondents, closing each of the education and income gaps in parents' expectations of their children's college attendance by almost 30 percent (and the recommendation gaps by 10 percent). We show that changes in college attendance expectations are partly a consequence of revisions in respondents' beliefs about self college returns. Finally, we confirm the persistence of these results with a follow-up survey two months later.

On the other hand, we find no descriptive or experimental evidence of a relationship between cost beliefs and expected college attendance. The lack of any meaningful impact of the cost experiment is somewhat surprising since respondents (1) do substantially revise beliefs regarding the child's college costs in a sensible way as a result of the cost information, and (2) find the cost information as credible as the returns information. One possible explanation for the muted impact of the cost experiment is that individuals discount costs/losses at a higher rate. However, given that costs to a college education are incurred much in advance of associated returns, the discount rate for costs would have to be substantially higher. This result remains a puzzle, and warrants future research.

Since expectations play a critical role in decision-making under uncertainty and, in particular, for human capital decisions which have substantial economic consequences (Cunha et al., 2005; Jacob and Linkow, 2011), the large and systematic biases regarding perceived college costs and benefits, and the sizable impacts in our (returns) information experiment, suggest a role for broader information campaigns focused on providing accurate information on schooling returns. Given the low cost of information interventions and large gaps in

\footnotetext{
${ }^{28}$ See, for example, Leonhart (2014) and Calmes (2014) in The New York Times.
} 
individuals' knowledge that we document, the policy case for conducting them is clear.

How effective information campaigns should be designed is beyond the scope of the current study. We believe this is challenging for several reasons. One, information regarding actual college costs and benefits is already in the public domain, in yearly reports like Baum and Ma (2013) and NCES (2013) and popular journalism like Pérez-Peña (2013a, 2013b); individuals' decision to ignore such information, to some extent, is endogenous, and hence it is not clear that simply providing this information would overcome gaps. Second, evidence on information interventions in developed settings is mixed. In fact, both Bettinger et al. (2012) and Hoxby and Turner (2013) find that information by itself has little impact, but leads to impacts only when combined with some nudge/subsidy (though both papers focus on college cost information interventions, without examining the impact of returns information). 


\section{References}

[1] Abdelaoui, M., A. Attema, and H. Bleichrodt. 2010. Intertemporal Tradeoffs for Gains and Losses: An Experimental Measurement of Discounted Utility. The Economic Journal, 120(545): 845-866.

[2] Altonji, J., L. Kahn, and J. Speer. 2014. Trends in Earnings Differentials across College Majors and the Changing Task Composition of Jobs. The American Economic Review, 104(5): 387-393.

[3] Attanasio, O, and K. Kaufmann. 2009. Education Choices and Returns on the Labour and Marriage Markets: Subjective Expectations, Gender and Decision Making. National Bureau of Economic Research Working Papers, 15087.

[4] Autor, D., L. Katz, and M. Kearney. 2008. Trends in US Wage Inequality: Revising the Revisionists. The Review of Economics and Statistics, 90(2): 300-323.

[5] Avery, C. and T. Kane. 2004. Student Perceptions of College Opportunities: The Boston COACH Program. In C. Hoxby, ed., College Choices: The Economics of Where to Go, When to Go, and How to Pay for It, 355-394. Chicago: University of Chicago Press.

[6] Bailey, M. J. and S. Dynarski. 2011. Inequality in Postsecondary Attainment. In G. Duncan and R. Murnane, eds., Whither Opportunity: Rising Inequality, Schools, and Children's Life Chances, 117-132. New York: Russell Sage Foundation.

[7] Baum, S. and J. Ma. 2013. Trends in College Pricing, 2013. Trends in Higher Education Series, 13b-8191. New York: The College Board.

[8] Beaman, L., E. Duflo, R. Pande and P. Topalova. 2012. Female Leadership Raises Aspirations and Educational Attainment for Girls: A Policy Experiment in India. Science Magazine, 335(6068): 582-586.

[9] Bettinger, E., B. Long, P. Oreopoulos, and L. Sanbonmatsu. 2012. The Role of Application Assistance and Information in College Decisions: Results from the H\&R Block Fafsa Experiment. Quarterly Journal of Economics, 127(3): 1205-1242.

[10] Betts, J. R. 1996. What Do Students Know about Wages? Evidence from a Survey of Undergraduates. Journal of Human Resources, 31(1): 27-56.

[11] Bound, J., M. Lovenheim, and S. Turner. 2010. Why Have College Completion Rates Declined? An Analysis of Changing Student Preparation and Collegiate Resources. American Economic Journal: Applied Economics, 2: 129-157.

[12] Calmes, J. 2014. Obama Lauds Pledges to Expand College Opportunities. The New York Times, 17 January 2014: A14. 
[13] Card, D. 1995. Using Geographic Variation in College Proximity to Estimate the Return to Schooling. In L. Christofides, E. Grant, and R. Swindinsky, eds., Aspects in Labour Economics: Essays in Honour of John Vanderkamp, 201-221. Toronto: University of Toronto Press.

[14] Carroll, S. and B. Sacerdote. Late Interventions Matter Too: The Case of College Coaching New Hampshire. National Bureau of Economic Research Working Papers, 19031.

[15] Cunha, F., J. Heckman, L. Lochner and D. Masterov. 2005. Interpreting the evidence on life cycle skill formation. In E. Hanushek and F. Welch, eds., Handbook of the Economics of Education 1, 697-812. Amsterdam: Elsevier B.V.

[16] Delavande, A. and S. Rohwedder. 2011. Differential Survival in Europe and the United States: Estimates Based on Subjective Probabilities of Survival. Demography, 48:13771400.

[17] Dellavigna, S. 2009. Psychology and Economics: Evidence from the Field. Journal of Economic Literature, 47: 315-372.

[18] Dinkelman, T., and C. Martínez. 2014. Investing in Schooling in Chile: The Role of Information about Financial Aid for Higher Education. Review of Economics and Statistics, 96(2): 244-257.

[19] Dominitz, J. and C. Manski. 1996. Eliciting Student Expectations of the Returns to Schooling. The Journal of Human Resources, 31(1): 1-26.

[20] Dominitz, J. 1998. Earnings Expectations, Revisions, and Realizations. Review of Economics and Statistics, 80: 374-388.

[21] Dynarski, S. and J. Scott-Clayton. 2013. Financial Aid Policy: Lessons from Research. The Future of Children, 23(1): 67-91.

[22] Heckman, J., L. Lochner, and P. Todd. 2006. Earnings Functions, Rates of Return and Treatment Effects: The Mincer Equation and Beyond. Handbook of the Economics of Education 1, 307-458. Amsterdam: Elsevier B.V.

[23] Horn, L., X. Chen, and C. Chapman. 2003. Getting Ready to Pay for College: What Students and Their Parents Know About the Cost of College Tuition and What They are Doing to Find Out. Washington, D.C.: National Center for Education Statistics, U.S. Department of Education.

[24] Hoxby, C., and S. Turner. 2013. Expanding College Opportunities for High-Achieving, Low Income Students. Stanford Institute for Economic Policy Research Discussion Paper No. 12-014. Stanford: Stanford University. 
[25] Jacob, B., and T. Linkow. 2011. Educational Expectation and Attainment. In G. Duncan and R. Mumane, eds., Whither Opportunity? Rising Inequality and the Uncertain Life Chances of Low-Income Children, 133-165. New York: Russell Sage Press.

[26] Jensen, R. 2010. The (perceived) returns to education and the demand for schooling. The Quarterly Journal of Economics, 125(2), 515-548.

[27] Leonhardt, D. 2014. A Case Study in Lifting College Attendance. The New York Times, 10 July 2014: A3.

[28] Lipkus, I., G. Samsa, and B. Rimer. 2001. General Performance on a Numeracy Scale among Highly Educated Samples. Medical Decision Making, 21(37): 37-44.

[29] Lochner, L. and A. Monge-Naranjo. 2012. Credit Constraints in Education. Annual Review of Economics, 4: 225-256.

[30] Loewenstein, G. and D. Prelec. 1992. Anomalies in Intertemporal Choice: Evidence and an Interpretation. The Quarterly Journal of Economics, 107(2): 573-597.

[31] Lusardi, A. 2009. Household Saving Behavior: The Role of Literacy, Information and Financial Education Programs. In C. Foote, L. Goette, and S. Meier, eds., Policymaking Insights from Behavioral Economics, 109-149. Boston: Federal Reserve Bank of Boston.

[32] McGuigan, M., S. McNally, and G. Wyness. 2012. Student Awareness of Costs and Benefits of Educational Decisions: Effects of an Information Campaign. Centre for the Economics of Education Discussion Papers, 139. London: London School of Economics.

[33] Murnane, R. 2013. U.S. High School Graduation Rates: Patterns and Explanations. Journal of Economic Literature, 51(2): 370-422.

[34] National Center for Education Statistics (NCES). 2013. The Condition of Education 2013. National Center for Education Statistics Annual Reports Program, 2013037. Washington, D.C.: U.S. Department of Education.

[35] Nguyen, T. 2008. Information, Role Models and Perceived Returns to Education: Experimental Evidence from Madagascar. Unpublished Manuscript.

[36] National Science Board (NSB). 2014. Science and Engineering Indicators 2014. National Science Foundation Special Reports, 14-01. Arlington, VA: National Science Foundation.

[37] Organisation for Economic Co-operation and Development (OECD). 2013. Education at a Glance 2013: OECD Indicators. Paris: OECD.

[38] Oreopoulos, P. and R. Dunn. 2013. Information and College Access: Evidence from a Randomized Field Experiment. Scandinavian Journal of Economics, 115(1): 3-26. 
[39] Oreopoulos, P., and U. Petronijevic. 2013. Making College Worth It: A Review of Research on the Returns to Higher Education. National Bureau of Economic Research Working Papers, 19053.

[40] Pérez-Peña, R. 2013a. Despite Rising Sticker Prices, Actual College Costs Stable Over Decade, Study Says. The New York Times, 24 October 2013: A14.

[41] Pérez-Peña, R. 2013b. What You Don't Know About Financial Aid (But Should). The New York Times, 9 April 2013: ED18.

[42] Reardon, S. and K. Bischoff. 2011. Income Inequality and Income Segregation. American Journal of Sociology, 116(4): 1092-1153.

[43] Schwarz, N, and L. Vaughn. 2002. The Availability Heuristic Revisited: Ease of Recall and Content of Recall as Distinct Sources of Information. In T. Gilovich, D. Griffin and D. Kahneman, eds., Heuristics and Biases: The Psychology of Intuitive Judgment, 103-119. New York: Cambridge University Press.

[44] Scott-Clayton, J. 2012. Information constraints and financial aid policy. National Bureau of Economic Research Working Papers, 17811.

[45] Smith, H. and B. Powell. 1990. Great Expectations: Variations in Income Expectations among College Seniors. Sociology of Education, 63(3): 194-207.

[46] Stinebrickner, T., and R. Stinebrickner. 2014. A Major in Science? Initial Beliefs and Final Outcomes for College Major and Dropout. Review of Economic Studies, 81(1): 426-472.

[47] Watson, T. 2009. Inequality and the Measurement of Residential Segregation by Income in American Neighborhoods. Review of Income and Wealth, 55: 820-844.

[48] Wiswall, M., and B. Zafar. 2015a. Determinants of College Major Choice: Identification Using an Information Experiment. Review of Economic Studies, 82(2): pp 791-824

[49] Wiswall, M, and B Zafar. 2015b. "How do College Students Respond to Public Information about Earnings?" Journal of Human Capital, 9(2): 117-169.

[50] Zwane, A., J. Zinman, E.Van Dusen, W. Pariente, C. Null, E. Miguel, M. Kremer, D. Karlan, R. Hornbeck, X. Giné, E. Duflo, F. Devoto, B. Crepon and A. Banerjee. 2011. "Being surveyed can change later behavior and related parameter estimates."Proceedings of the National Academy of Sciences, 10(1073): 1-6. 


\section{Appendix A: Questionnaire}

\section{Main Survey}

We would next like to ask you a few questions about education.

Q1. What is the highest level of school you have completed, or the highest degree you have received?

- Less than high school

- High school diploma (or equivalent)

- Some college but no degree

- Associate/Junior College degree

- Bachelor's Degree (For example: BA, BS)

- Master's Degree (For example: MA, MBA, MS, MSW)

- Doctoral Degree (For example: PhD)

- Professional Degree (For example: MD, JD, DDS)

- Other (please specify)

Q2. Have you or any other member of your household ever taken out a student loan? Please select all that apply.

1. I have taken out a student loan

2. My spouse has taken out a student loan

3. My child (or children) has taken out a student loan

4. None of the above

Q3. Roughly speaking, what are your current annual earnings, before taxes and other deductions?

[If Q1 $\geq$ Bachelor's Degree] Q4a. Roughly speaking, what do you think your annual earnings would be, before taxes and other deductions, IF you only had a high school diploma?

[If Q1 < Bachelor's Degree] Q4b. Roughly speaking, what do you think your annual earnings would be, before taxes and other deductions, IF you only had a Bachelor's Degree? 
Q5a. Consider all non-college individuals (that is, individuals without a Bachelor's degree) currently aged 40 who are working full time right now. What do you believe is the average amount that these workers currently earn per year, before taxes and other deductions? dollars per year

Q5b. Consider all college graduate individuals (that is, individuals with at least a Bachelor's degree) currently aged 40 who are working full time right now. What do you believe is the average amount that these workers currently earn per year, before taxes and other deductions? dollars per year

Q6a. Sticker cost is a college's published cost of attendance. The cost of attendance includes tuition, fees and housing as well as other important costs like books, supplies and transportation. What is your best guess of the current average annual sticker cost of a 4-year Bachelor's degree at a:

public university?

nonprofit private university?

Q6b. Many students who go to college qualify for grants and scholarships (money that students get that they don't have to work for or pay back), and as a result end up paying less than the sticker cost. This cost of college after taking into account grants and scholarships is referred to as the net college cost. This is the amount that students actually have to pay. What is your best guess of the current average annual net cost of a 4-year Bachelor's degree at a:

public university?

nonprofit private university?

Q7a. Do you have any children under the age of 18 ?

- Yes, __ child/children

- No

[If Q7a = yes] Q7b. Consider the oldest child in your household under the age of 18. How many years old is this child? [show drop-down menu that goes from 1 to 18 ]

[If Q7a = yes] Q8a. Consider the oldest child in your household under the age of 18. What is the percent chance that this child will attend college in the future?

[If Q7a = yes] Q8b. If this child were to attend college, what do you think the annual net college cost (the cost that the child and/or the family will actually have to pay) would be? Please ignore the effects of inflation. 
[If Q7a = yes and Q8a > 0] Q8c. What is the percent chance that you or this child would have to take out a student loan for the child's college education?

[If Q7a = yes ] Q8d. And, what is the percent chance that this child will attend college if college was totally free (that is, the cost was zero)?

[If Q7a = yes ] Q9. Look ahead to when this child will be 30 years old, and working full time. Think about the child's earnings at age 30. When answering these questions, please ignore the effects of price inflation on earnings. That is, assume that one dollar today is worth the same as one dollar when the child is 30 years old. What do you think the child will be earning annually, before taxes and other deductions, at age 30:

- if he/she had at least a Bachelor's Degree?

- if he/she did not have a 4-year college degree?

Q10. A friend of yours has sought your advice about whether to send their 15-year old child to college for a 4-year degree. The child is currently in high school and performing well. What is the percent chance that you would recommend a college education for the child to your friend?

[If Q7a = no] Q11. Look ahead to when this child will be 30 years old, and working full time. Think about the child's earnings at age 30. When answering these questions, please ignore the effects of price inflation on earnings. That is, assume that one dollar today is worth the same as one dollar when the child is 30 years old. What do you think the child will be earning annually, before taxes and other deductions, at age 30:

- if he/she had at least a Bachelor's Degree?

- if he/she did not have a 4-year college degree?

Respondents are randomly placed into one of three equally-sized blocks: A, B, and $\mathrm{C}$.

\section{Questions for Block A}

[Note: all information and questions below are shown on the same page, but sequentially]

Earlier in the survey you stated that you think current 40-year-old college-educated individuals (that is, individuals with at least a Bachelor's degree) working full-time earn $\$[\mathrm{Q} 5 \mathrm{~b}]$ per year on average, and that non-college individuals earn $\$[\mathrm{Q} 5 \mathrm{a}]$ per year.

That is you think, on average, college-educated workers earn [Q5b/Q5a] times as much as non-college workers (that is, [(Q5b/Q5a-1)*100]\% [more/less $]$ ). 
Analysis based on the 2012-2013 Current Population Survey shows that collegeeducated full-time workers in fact earn $\underline{\mathbf{1 . 8 0}}$ times as much as non-college workers (that is, $80 \%$ more than non-college workers)

The Current Population Survey is a survey jointly sponsored by the US Bureau of Labor Statistics and the Census Bureau.

Q12. On a scale of 1-5, how credible and useful do you find this information?

1. Absolutely not credible/useful

2. Absolutely credible/useful

In light of this information, we would like to re-ask some questions.

[If Q7a = yes] Q13a. Again consider the oldest child in your household under the age of 18. What is the percent chance that this child will attend college in the future?

[If Q7a = yes] Q13b. If this child were to attend college, what do you think the annual net college cost (the cost that the child and/or the family will actually have to pay) would be? Please ignore the effects of inflation.

[If Q7a = yes] Q13c. And, what is the percent chance that this child will attend college if college was totally free (that is, the cost was zero)?

[If Q7a = yes] Q14. As before, look ahead to when this child will be 30 years old, and working full time. Think about the child's earnings at age 30. When answering these questions, please ignore the effects of price inflation on earnings. That is, assume that one dollar today is worth the same as one dollar when the child is 30 years old. What do you think the child will be earning annually, before taxes and other deductions, at age 30:

- if he/she had at least a Bachelor's Degree?

- if he/she did not have a 4-year college degree?

Q15. A friend of yours has sought your advice about whether to send their 15-year old child to college for a 4-year degree. The child is currently in high school and performing well. What is the percent chance that you would recommend a college education for the child to your friend?

[If Q7a = no] Q16. As before, look ahead to when this child will be 30 years old, and working full time. Think about the child's earnings at age 30. When answering these questions, please ignore the effects of price inflation on earnings. That is, assume that one dollar today is worth the same as one dollar when the child is 30 years old. What do you think the child will be earning annually, before taxes and other deductions, at age 30: 
- if he/she had at least a Bachelor's Degree?

- if he/she did not have a 4-year college degree?

\section{Questions for Block B}

[Note: all information and questions below are shown on the same page, but sequentially]

Earlier in the survey we had asked you about college net costs. This is the cost of college after taking into account grants and scholarships (money that students get that they don't have to work for or pay back), and is the price that students actually have to pay. In many cases, this is less than the published college cost (the sticker cost).

You had stated that you expect the average annual net cost of a Bachelor's degree at a 4-year public university to be $\$ \underline{\text { Q6a1] }}$ and at a 4-year nonprofit private university to be $\$[$ Q6a2].

According to the College Board Annual Survey of Colleges, the average annual net cost of a 4-year public university in $2013-2014$ was $\$ 12,620$, while that of a 4-year nonprofit private university was $\$ 23,290$.

Q12. On a scale of 1-5, how credible and useful do you find this information?

1. Absolutely not credible/useful

2. Absolutely credible/useful

In light of this information, we would like to re-ask some questions.

[If Q7a = yes] Q13a. Again consider the oldest child in your household under the age of 18. What is the percent chance that this child will attend college in the future?

[If Q7a = yes] Q13b. If this child were to attend college, what do you think the annual net college cost (the cost that the child and/or the family will actually have to pay) would be? Please ignore the effects of inflation.

[If Q7a = yes] Q13c. And, what is the percent chance that this child will attend college if college was totally free (that is, the cost was zero)?

[If Q7a = yes] Q14. As before, look ahead to when this child will be 30 years old, and working full time. Think about the child's earnings at age 30. When answering these questions, please ignore the effects of price inflation on earnings. That is, assume that one dollar today is worth the same as one dollar when the child is 30 years old. What do you think the child will be earning annually, before taxes and other deductions, at age 30: 
- if he/she had at least a Bachelor's Degree?

- if he/she did not have a 4-year college degree?

Q15. A friend of yours has sought your advice about whether to send their 15-year old child to college for a 4-year degree. The child is currently in high school and performing well. What is the percent chance that you would recommend a college education for the child to your friend?

[If Q7a = no] Q16. As before, look ahead to when this child will be 30 years old, and working full time. Think about the child's earnings at age 30. When answering these questions, please ignore the effects of price inflation on earnings. That is, assume that one dollar today is worth the same as one dollar when the child is 30 years old. What do you think the child will be earning annually, before taxes and other deductions, at age 30:

- if he/she had at least a Bachelor's Degree?

- if he/she did not have a 4-year college degree?

\section{Questions for Block C}

[Note: all information and questions below are shown on the same page, but sequentially]

Earlier in the survey you stated that you think current 40-year-old college-educated individuals (that is, individuals with at least a Bachelor's degree) working full-time earn $\$[\mathrm{Q} 5 \mathrm{~b}]$ per year on average, and that non-college individuals earn $\$[\mathrm{Q} 5 \mathrm{a}]$ per year. That is you think, on average, college-educated workers earn [Q5b/Q5a] times as much as non-college workers (that is, [(Q5b/Q5a-1)*100]\% [more/less]).

We had also asked you about college net costs. This is the cost of college after taking into account grants and scholarships (money that students get that they don't have to work for or pay back), and is the price that students actually have to pay. In many cases, this is less than the published college cost (the sticker cost). You had stated that you expect the average annual net cost of a Bachelor's degree at a 4-year public university to be $\$ \underline{\text { [Q6a1] }}$ and at a 4-year nonprofit private university to be $\$ \underline{\text { [Q6a2] }}$.

[If Q7a = yes] Q13a. Again consider the oldest child in your household under the age of 18. What is the percent chance that this child will attend college in the future?

[If Q7a = yes] Q13c. And, what is the percent chance that this child will attend college if college was totally free (that is, the cost was zero)? 
Q15. A friend of yours has sought your advice about whether to send their 15-year old child to college for a 4-year degree. The child is currently in high school and performing well. What is the percent chance that you would recommend a college education for the child to your friend?

\section{Follow-up Survey}

We would next like to ask you a few questions about education.

Q5a. Consider all non-college individuals (that is, individuals without a Bachelor's degree) currently aged 40 who are working full time right now. What do you believe is the average amount that these workers currently earn per year, before taxes and other deductions? dollars per year

Q5b. Consider all college graduate individuals (that is, individuals with at least a Bachelor's degree) currently aged 40 who are working full time right now. What do you believe is the average amount that these workers currently earn per year, before taxes and other deductions? dollars per year

Q6b. Many students who go to college qualify for grants and scholarships (money that students get that they don't have to work for or pay back), and as a result end up paying less than the sticker cost. This cost of college after taking into account grants and scholarships is referred to as the net college cost. This is the amount that students actually have to pay. What is your best guess of the current average annual net cost of a 4-year Bachelor's degree at a:

public university?

nonprofit private university?

Q7a. Do you have any children under the age of 18 ?

- Yes, child/children

- No

[If Q7a = yes] Q8a. Consider the oldest child in your household under the age of 18. What is the percent chance that this child will attend college in the future?

[If Q7a = yes] Q8b. If this child were to attend college, what do you think the annual net college cost (the cost that the child and/or the family will actually have to pay) would be? Please ignore the effects of inflation.

Q10. A friend of yours has sought your advice about whether to send their 15-year old child to college for a 4-year degree. The child is currently in high school and performing well. 
What is the percent chance that you would recommend a college education for the child to your friend?

\section{Appendix B: Examples Regarding Response to Infor- mation}

We next provide two examples of possible ways individuals could update their self expectations when they receive new information about population earnings.

In the first example, the household head believes that earnings are the product of an individual's level of skill and the skill price per unit of skill. The household head is certain about her child's level of skill but uncertain about the skill price. She uses the (perceived) average population earnings of college graduates (relative to non-college workers) to infer skill prices. If this individual underestimates true population college earnings (and, hence, underestimates skill prices), her beliefs about her child's relative college earnings would also be biased downward. In this example, self earnings beliefs and population earnings beliefs are positively linked, and had the individual been provided with accurate information about population earnings (which are higher than her ex ante beliefs), she would revise her beliefs about her child's college earnings upwards. And if earnings positively impact the likelihood of attending college, then the individual would revise upward her beliefs regarding the child's college attendance.

In the second example, the household head believes earnings are based on the individual's level of skill relative to the population average skill. The household head is certain about the level of the child's skill but uncertain about the population average level of skill. She uses the (perceived) average population earnings of college graduates to infer the average relative level of skill of college graduates. If she underestimates true population college earnings (and, hence, underestimates the average population skill level), she is overestimating her child's relative position in the population skill distribution. In this case, where earnings are based on the individuals' relative skills, underestimation of population college earnings would lead the individual to overestimate beliefs about her child's college earnings (that is, the two are negatively linked). Providing accurate information about population beliefs in this case would lead the individual to revise her beliefs about her child's college earnings (and college attendance) downwards. 
Figure 1: Distribution of Perceived Average Population RCE

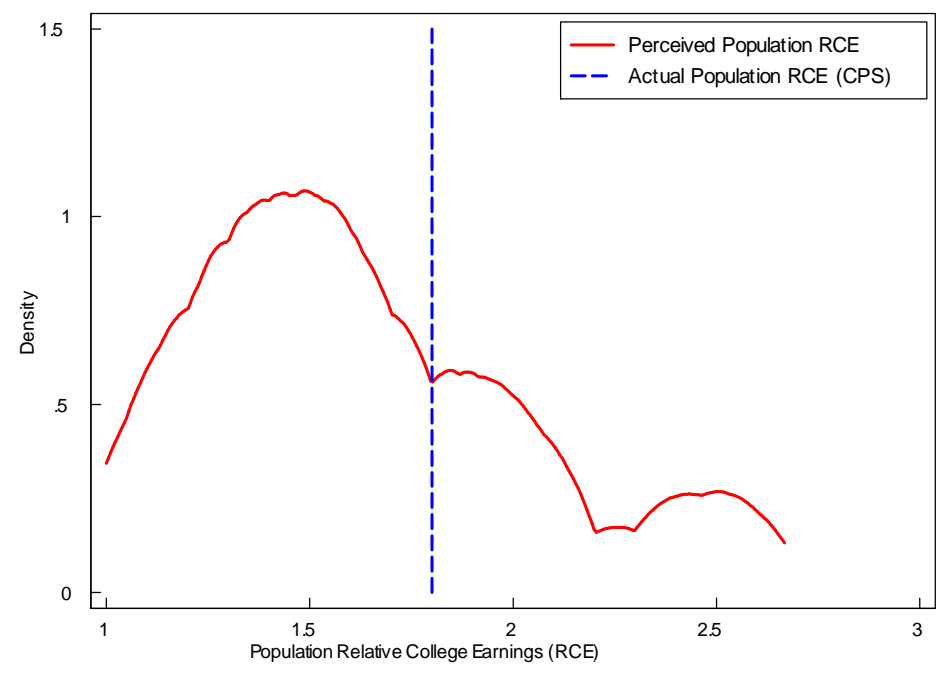

Figure 2: Distribution of Perceived Average Public and Private University Costs
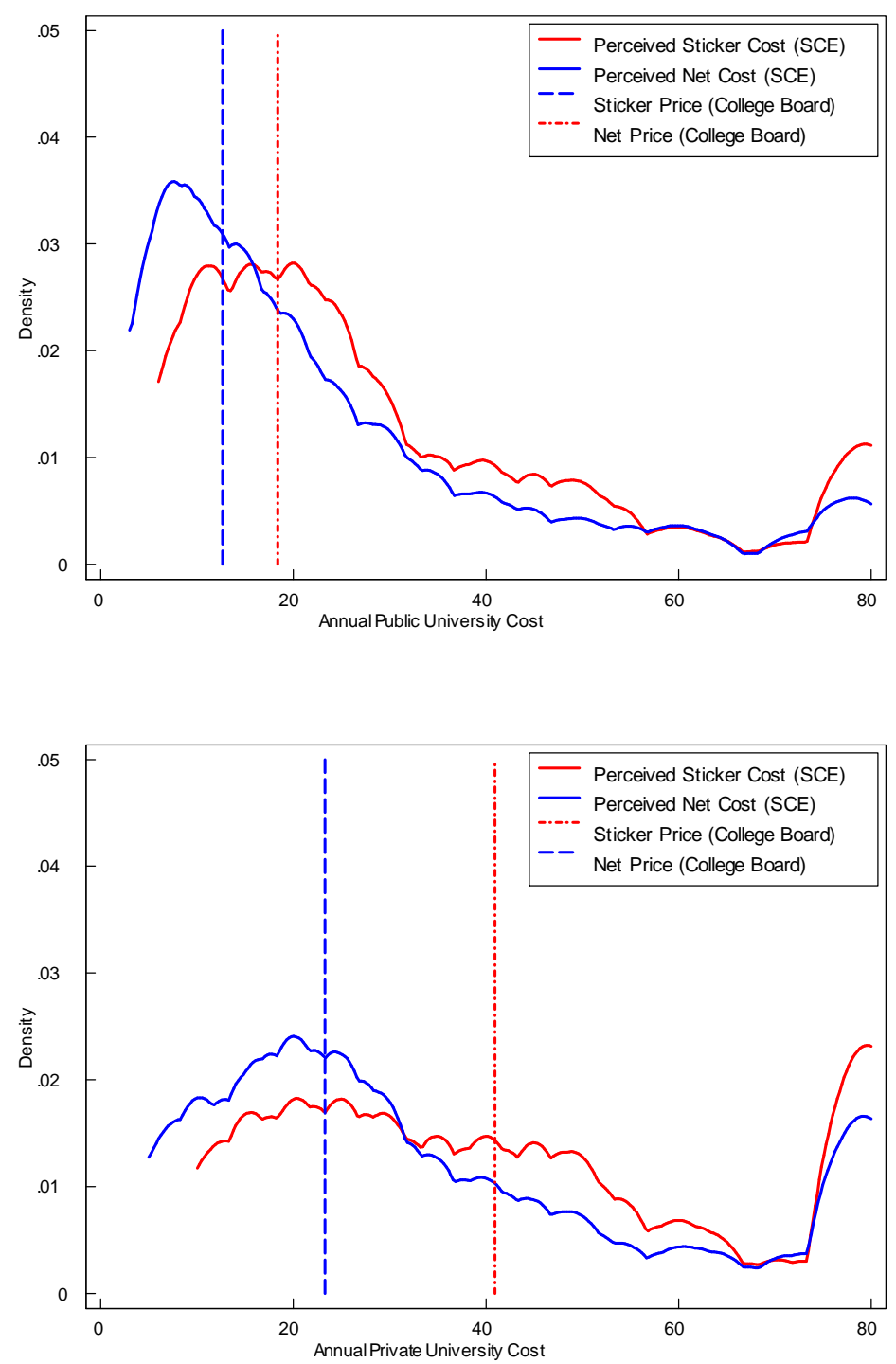


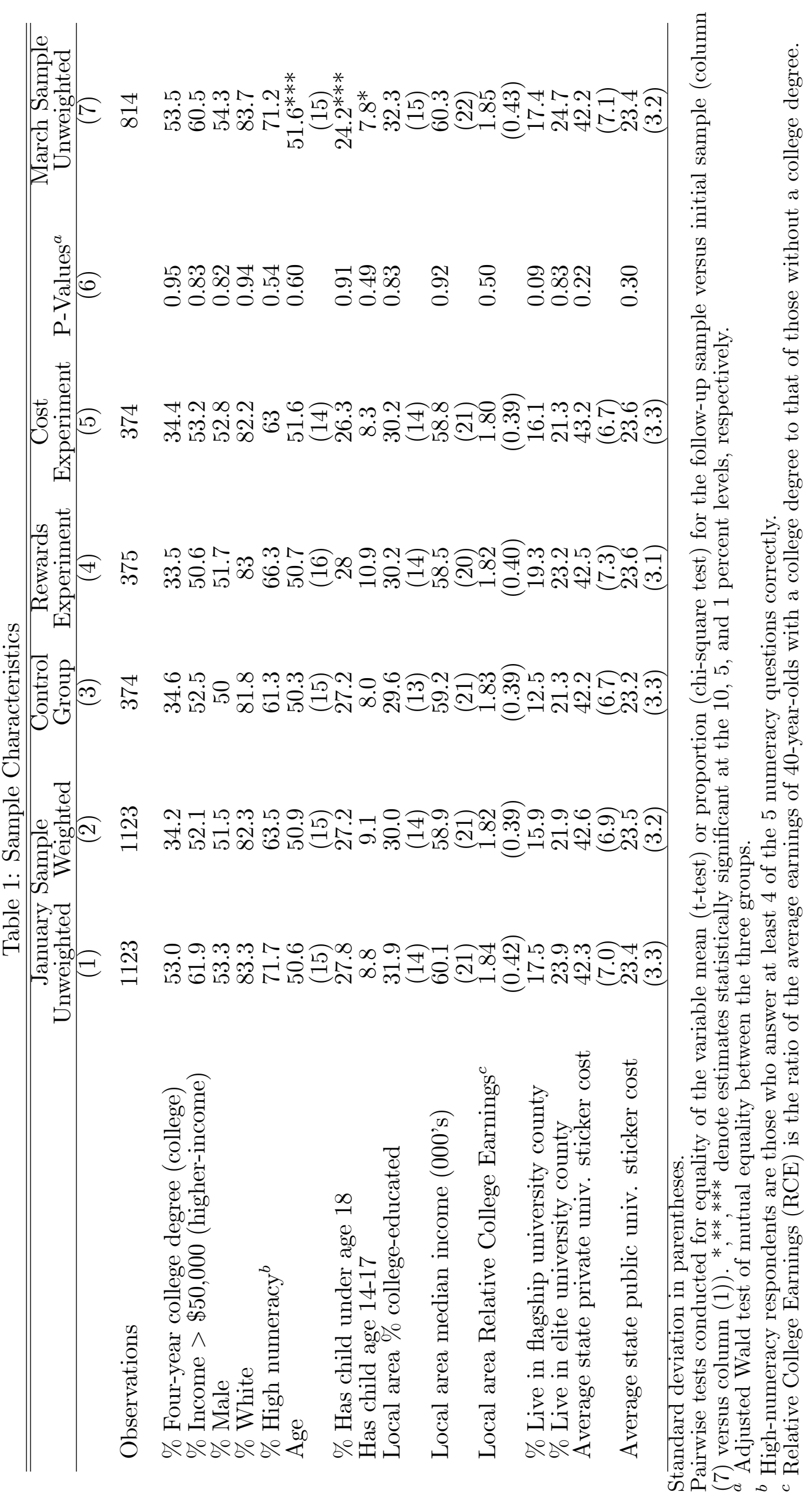




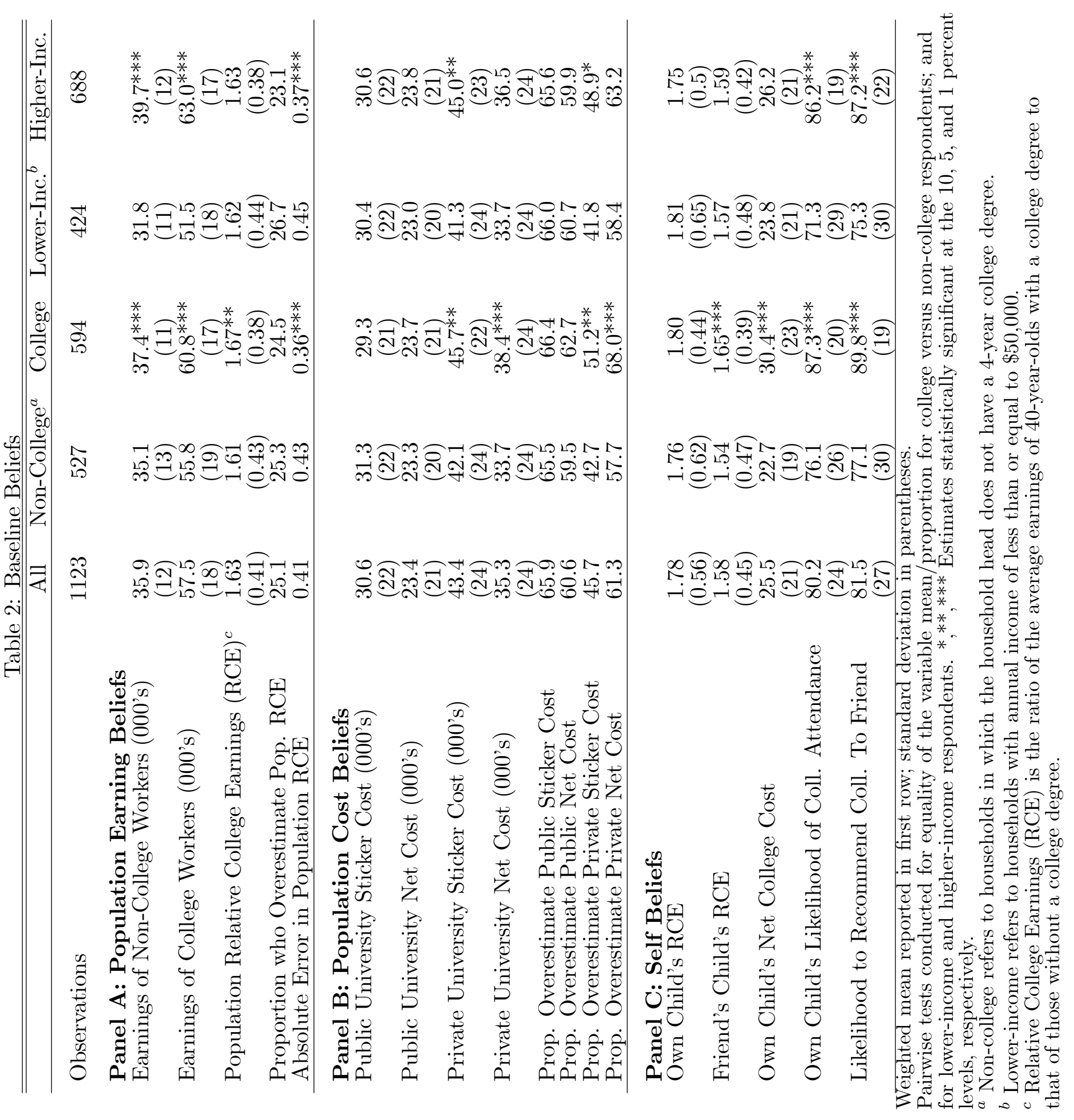


Table 3: Self Beliefs and Population Beliefs

\begin{tabular}{|c|c|c|c|c|}
\hline Dependent variable: & Own Child's RCE ${ }^{a}$ & Friend's Child's RCE & \multirow{2}{*}{\multicolumn{2}{|c|}{$\begin{array}{l}\text { Own Child's Net Cost } \\
(3)\end{array}$}} \\
\hline & $(1)$ & $(2)$ & & \\
\hline Population $\mathrm{RCE}^{a}$ & $\begin{array}{c}0.66^{* * *} \\
(0.10)\end{array}$ & $\begin{array}{c}0.44^{* * *} \\
(0.056)\end{array}$ & & \\
\hline Pop. Public Net Cost & & & $0.52 * * *$ & $0.40^{* *}$ \\
\hline Pop. Public Sticker Cost & & & & $\begin{array}{l}(0.10) \\
-0.025 \\
(0.15)\end{array}$ \\
\hline Pop. Private Net Cost & & & & -0.027 \\
\hline Pop. Private Sticker Cost & & & & $0.30^{* *}$ \\
\hline Constant & $\begin{array}{c}0.43 \\
(0.76)\end{array}$ & $\begin{array}{c}1.06^{* * * *} \\
(3.94)\end{array}$ & $\begin{array}{c}20.2 \\
(1.50)\end{array}$ & $\begin{array}{c}10.9 \\
(0.87)\end{array}$ \\
\hline $\begin{array}{l}\text { Demographics }{ }^{b} \\
\text { F-statistic }^{c} \\
\mathrm{R}^{2} \\
\text { Number of Observations } \\
\text { Mean of Dep. Var. }\end{array}$ & $\begin{array}{c}\text { Yes } \\
5.30^{* * *} \\
0.26 \\
306 \\
1.8\end{array}$ & $\begin{array}{c}\text { Yes } \\
8.56^{* * *} \\
0.19 \\
785 \\
1.6\end{array}$ & $\begin{array}{c}\text { Yes } \\
8.01^{* * *} \\
0.29 \\
306 \\
25\end{array}$ & $\begin{array}{c}\text { Yes } \\
10.4^{* * *} \\
0.35 \\
306 \\
25\end{array}$ \\
\hline
\end{tabular}

Weighted OLS estimates of a regression of the dependent variable on various controls.

Robust standard errors in parentheses. ${ }^{*}, * *, * * *$ denote significance at the 10,5 , and $1 \%$ levels, respectively.

${ }^{a}$ Relative College Earnings (RCE) is the ratio of the average earnings of 40-year-olds with a college degree to that of those without a college degree.

${ }^{b}$ Demographics include controls for low-income, non-college, male, white, age, high-numeracy, has child under age 18, has child aged 14-17, local area \% BAs, local area income, local area RCE, flagship county, elite university county, state public university cost, and state private university cost.

${ }^{c}$ F-statistic for a joint test of the significance of the covariates. 
Table 4: College Attendance Expectations and Beliefs

\begin{tabular}{|c|c|c|c|c|c|c|}
\hline Dependent variable: & \multicolumn{3}{|c|}{ Own Child's Attendance $^{a}$} & \multicolumn{3}{|c|}{ Friend's Child's Attendance ${ }^{b}$} \\
\hline & $(1)$ & $(2)$ & $(3)$ & $(4)$ & $(5)$ & $(6)$ \\
\hline Population RCE & $\begin{array}{c}6.12^{*} \\
(3.4)\end{array}$ & & $\begin{array}{l}3.66 \\
(4.4)\end{array}$ & $\begin{array}{c}9.02^{* * * *} \\
(2.7)\end{array}$ & & $\begin{array}{l}1.59 \\
(3.6)\end{array}$ \\
\hline Pop. Public Net Cost & 0.10 & & 0.039 & 0.006 & & -0.014 \\
\hline Own Child's RCE ${ }^{c}$ & $(0.069)$ & 4.26 & $\begin{array}{c}(0.085) \\
3.20 \\
(32)\end{array}$ & $(0.056)$ & & $(0.064)$ \\
\hline Friend's Child's RCE & & & & & $\begin{array}{c}16.4^{* * *} \\
(2.9)\end{array}$ & $\begin{array}{c}15.4^{* * *} \\
(3.4)\end{array}$ \\
\hline Own Child's Net College Cost & & $\begin{array}{c}0.16^{* *} \\
(0.071)\end{array}$ & $\begin{array}{c}0.13 \\
(0.086)\end{array}$ & & & \\
\hline Constant & $\begin{array}{c}93.2^{* * *} \\
(16)\end{array}$ & $\begin{array}{c}97.1 * * * \\
(15)\end{array}$ & $\begin{array}{c}91.7^{* * *} \\
(16)\end{array}$ & $\begin{array}{c}72.5^{* * *} \\
(12)\end{array}$ & $\begin{array}{c}64.8^{* * *} \\
(13)\end{array}$ & $\begin{array}{c}60.6^{* * *} \\
(14)\end{array}$ \\
\hline Demographics $^{d}$ & Yes & Yes & Yes & Yes & Yes & Yes \\
\hline F-statistic ${ }^{e}$ & $2.67^{* * *}$ & $2.63^{* * *}$ & $2.72^{* * *}$ & $5.92 * * *$ & $6.59 * * *$ & $6.25^{* * *}$ \\
\hline $\mathrm{R}^{2}$ & 0.21 & 0.21 & 0.22 & 0.14 & 0.18 & 0.18 \\
\hline f Obser & 305 & 307 & 305 & 1079 & 792 & 772 \\
\hline Mean of Dep. Var. & 80 & 80 & 80 & 82 & 80 & 80 \\
\hline
\end{tabular}

Weighted OLS estimates of a regression of the dependent variable on various controls.

Robust standard errors in parentheses. ${ }^{* * *},{ }^{* * *}$ denote significance at the 10,5 , and $1 \%$ levels, respectively.

${ }^{a}$ The expected likelihood of a respondent's child attending college.

${ }^{b}$ The expected likelihood of a respondent recommending college for a friend's 15-year-old child.

${ }^{c}$ Relative College Earnings (RCE) is the ratio of the average earnings of 40-year-olds with a college degree to that of those without a college degree.

${ }^{d}$ See Table 3 notes for the demographics that are included.

${ }^{e}$ F-statistic for a joint test of the significance of the covariates. 


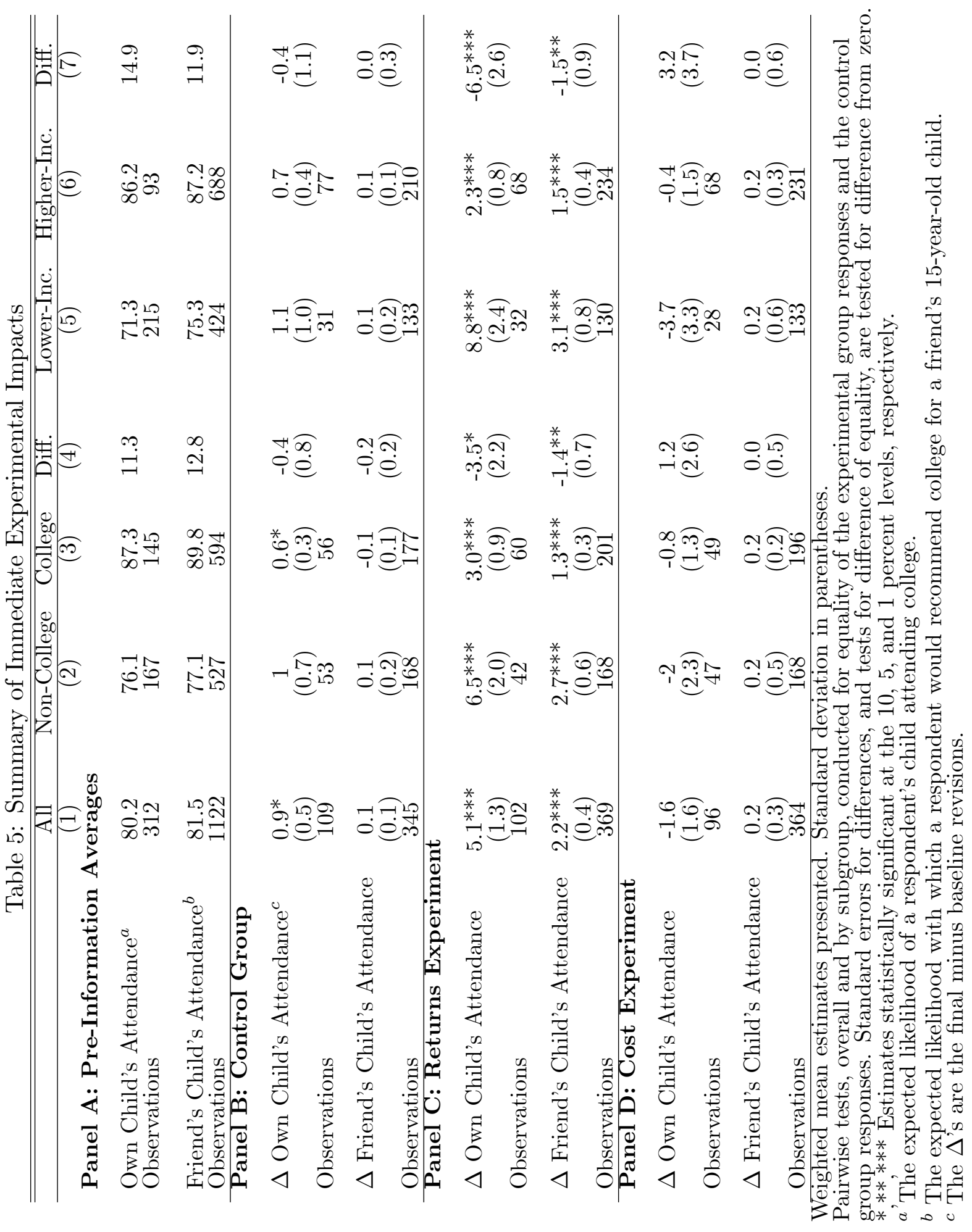




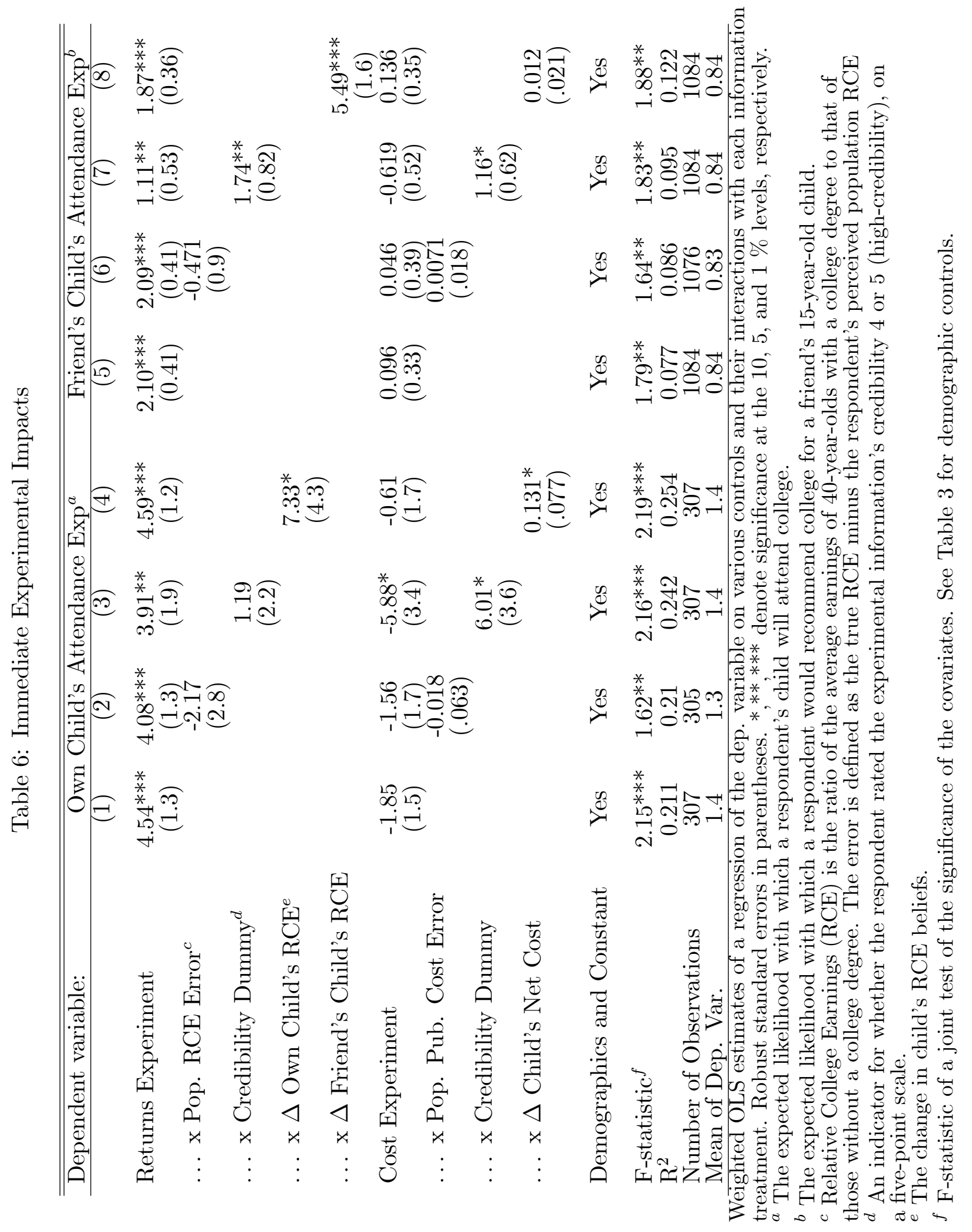




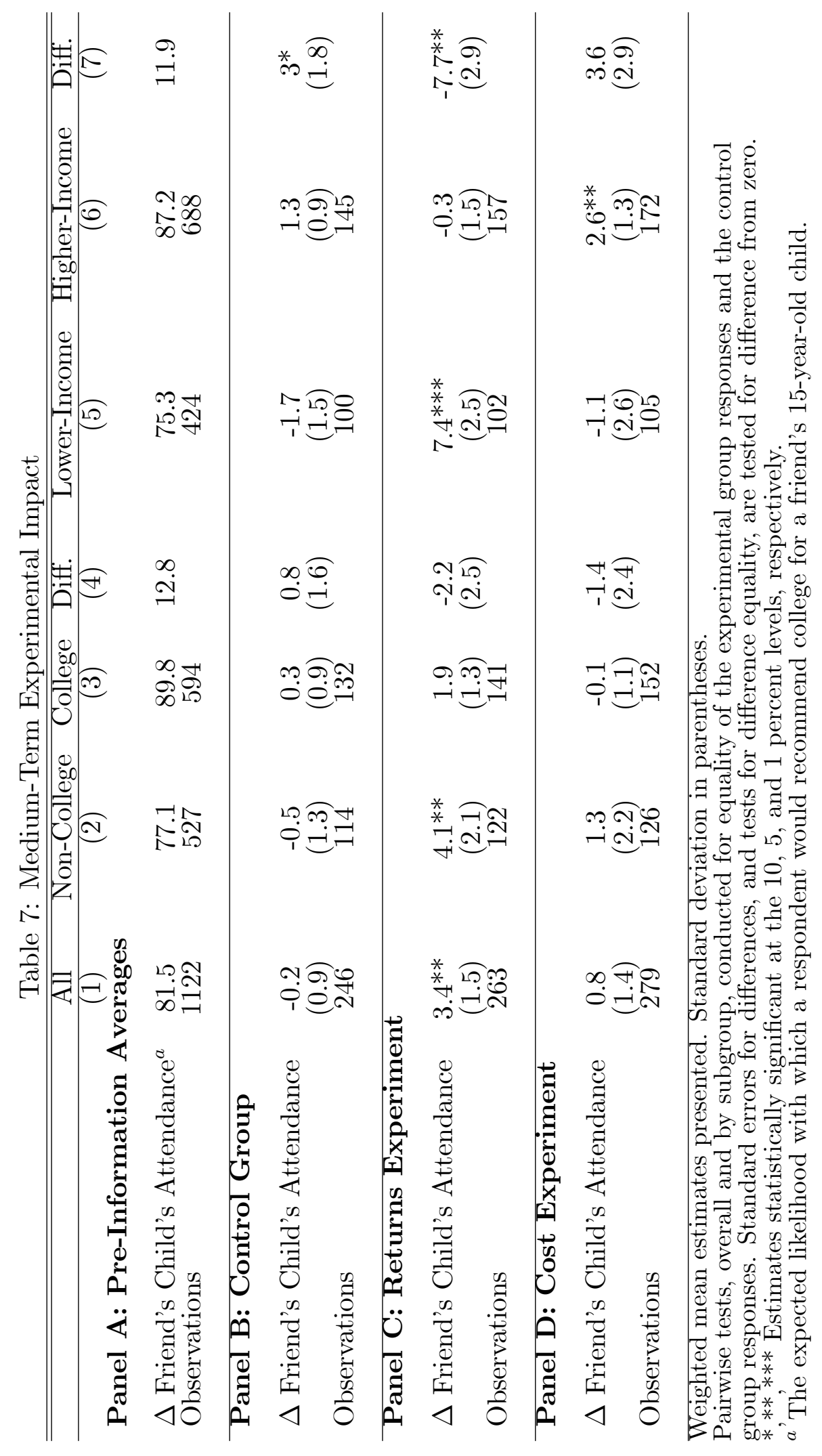


Table A1: Selection into the Follow-up Survey

\begin{tabular}{|c|c|c|c|}
\hline ep Var: Participation in the & $\frac{\text { low-up S }}{(1)}$ & $(2)$ & (3) \\
\hline Population RCE Belief ${ }^{a}$ & & $\begin{array}{c}0.036 \\
(0.033)\end{array}$ & $\begin{array}{c}0.12 \\
(0.093)\end{array}$ \\
\hline Pub. Univ. Net Cost Belief ${ }^{b}$ & & $\begin{array}{l}-0.001 \\
(0.001)\end{array}$ & $\begin{array}{l}0.003^{*} \\
(0.002)\end{array}$ \\
\hline Child $\mathrm{RCE}^{c}$ & & & $\begin{array}{l}-0.074 \\
(0.072)\end{array}$ \\
\hline Child Net Univ. Cost $^{c}$ & & & $\begin{array}{r}-0.003^{*} \\
(0.002)\end{array}$ \\
\hline Child's college likelihood $^{d}$ & & & $\begin{array}{l}-0.002 \\
(0.002)\end{array}$ \\
\hline Friend's child's likelihood ${ }^{e}$ & & & $\begin{array}{c}0.000 \\
(0.002)\end{array}$ \\
\hline RCE Experiment Dummy & $\begin{array}{l}-0.003 \\
(0.036)\end{array}$ & $\begin{array}{l}-0.005 \\
(0.036)\end{array}$ & $\begin{array}{c}0.024 \\
(0.077)\end{array}$ \\
\hline Cost Experiment Dummy & $\begin{array}{l}0.028 \\
(0.037)\end{array}$ & $\begin{array}{c}0.016 \\
(0.037)\end{array}$ & $\begin{array}{c}0.12 \\
(0.076)\end{array}$ \\
\hline Low Income & $\begin{array}{c}0.042 \\
(0.035)\end{array}$ & $\begin{array}{c}0.046 \\
(0.036)\end{array}$ & $\begin{array}{c}0.10 \\
(0.083)\end{array}$ \\
\hline Non-College & $\begin{array}{r}-0.028 \\
(0.03)\end{array}$ & $\begin{array}{r}-0.023 \\
(0.03)\end{array}$ & $\begin{array}{l}-0.13^{*} \\
(0.068)\end{array}$ \\
\hline Male & $\begin{array}{c}0.036 \\
(0.031)\end{array}$ & $\begin{array}{l}0.040 \\
(0.03)\end{array}$ & $\begin{array}{c}0.10 \\
(0.063)\end{array}$ \\
\hline White & $\begin{array}{c}0.013 \\
(0.046)\end{array}$ & $\begin{array}{c}0.025 \\
(0.047)\end{array}$ & $\begin{array}{l}-0.11 \\
(0.069)\end{array}$ \\
\hline Age & $\begin{array}{c}0.004^{* * * *} \\
(0.001)\end{array}$ & $\begin{array}{c}0.004^{* * *} \\
(0.001)\end{array}$ & $\begin{array}{l}0.005 \\
(0.004)\end{array}$ \\
\hline High Numeracy & $\begin{array}{l}-0.006 \\
(0.035)\end{array}$ & $\begin{array}{l}-0.009 \\
(0.035)\end{array}$ & $\begin{array}{c}0.034 \\
(0.075)\end{array}$ \\
\hline Has Child Under Age 18 & $\begin{array}{c}-0.14^{* * *} * \\
(0.052)\end{array}$ & $\begin{array}{c}-0.12^{* *} \\
(0.051)\end{array}$ & \\
\hline Has Child Age 14-17 & $\begin{array}{c}0.11 \\
(0.068)\end{array}$ & $\begin{array}{l}0.089 \\
(0.068)\end{array}$ & $\begin{array}{c}0.063 \\
(0.082)\end{array}$ \\
\hline Local Area \% BAs & $\begin{array}{l}-0.000 \\
(0.002)\end{array}$ & $\begin{array}{l}0.001 \\
(0.002)\end{array}$ & $\begin{array}{l}-0.001 \\
(0.005)\end{array}$ \\
\hline Local Area Median Inc (000s) & $\begin{array}{c}0.001 \\
(0.001)\end{array}$ & $\begin{array}{c}0.000 \\
(0.001)\end{array}$ & $\begin{array}{l}-0.000 \\
(0.003)\end{array}$ \\
\hline Local Area RCE & $\begin{array}{c}0.030 \\
(0.042)\end{array}$ & $\begin{array}{c}0.003 \\
(0.039)\end{array}$ & $\begin{array}{c}-0.062 \\
(0.11)\end{array}$ \\
\hline Flagship County & $\begin{array}{l}-0.036 \\
(0.045)\end{array}$ & $\begin{array}{l}-0.037 \\
(0.044)\end{array}$ & $\begin{array}{c}0.042 \\
(0.076)\end{array}$ \\
\hline Elite University County & $\begin{array}{c}0.025 \\
(0.037)\end{array}$ & $\begin{array}{c}0.030 \\
(0.037)\end{array}$ & $\begin{array}{l}0.087 \\
0.08)\end{array}$ \\
\hline State Pub. Univ. Sticker Cost & $\begin{array}{l}-0.002 \\
(0.003)\end{array}$ & $\begin{array}{l}-0.001 \\
(0.003)\end{array}$ & $\begin{array}{c}0.001 \\
(0.005)\end{array}$ \\
\hline State Priv. Univ. Sticker Cost & $\begin{array}{c}0.004 \\
(0.005)\end{array}$ & $\begin{array}{c}0.004 \\
(0.005)\end{array}$ & $\begin{array}{c}0.001 \\
(0.011)\end{array}$ \\
\hline Constant & $\begin{array}{c}0.49 * * * \\
(0.15)\end{array}$ & $\begin{array}{c}0.44^{* * *} \\
(0.16)\end{array}$ & $\begin{array}{c}0.50 \\
(0.39)\end{array}$ \\
\hline F-statistic ${ }^{f}$ & $3.4^{* * *}$ & $3.4^{* * *}$ & $1.5^{* * *}$ \\
\hline $\mathrm{R}^{2}$ & 0.067 & 0.0 & 0.115 \\
\hline $\begin{array}{l}\text { Number of Observations } \\
\text { Mean of Dep. Variable }\end{array}$ & $\begin{array}{c}978 \\
0.81\end{array}$ & $\begin{array}{l}953 \\
0.81\end{array}$ & $\begin{array}{l}272 \\
0.7\end{array}$ \\
\hline
\end{tabular}

Weighted OLS estimates of a linear probability model for participation in the follow-up survey on various controls. Robust standard errors in parentheses. $*, * *, * * *$ denote significance at the 10,5 , and $1 \%$ levels,respectively.

${ }^{a}$ Relative College Earnings (RCE) is the ratio of the average earnings of 40-year-olds with a college degree to that of those without a college degree.

${ }^{b}$ Population public university net cost belief.

${ }^{c} \mathrm{RCE}$ and public university net cost beliefs for one's own child.

$d$ The expected likelihood of a respondent's child attending college.

$e$ The expected likelihood of a respondent recommending college for a friend's child.

${ }^{f}$ F-statistic of a test of the joint significance of the covariates. 
Table A2: Heterogeneity in Baseline Population Beliefs

\begin{tabular}{|c|c|c|c|c|}
\hline Dependent variable: & $\begin{array}{c}\begin{array}{c}\text { Population } \\
\text { RCE }^{a}\end{array} \\
\text { (1) }\end{array}$ & $\begin{array}{c}\text { Abs. Err. in } \\
\text { Pop. RCE } \\
(2)\end{array}$ & $\begin{array}{c}\text { Pop. Public } \\
\text { Sticker Cost } \\
\text { (3) }\end{array}$ & $\begin{array}{c}\text { Pop. Private } \\
\text { Sticker Cost } \\
\text { (4) }\end{array}$ \\
\hline Non-college & $\begin{array}{c}-0.049 \\
-1.6)\end{array}$ & $\begin{array}{c}0.045^{* *} \\
(2.3)\end{array}$ & $\begin{array}{c}1.5 \\
(0.97)\end{array}$ & $\begin{array}{c}-0.87 \\
(-0.61)\end{array}$ \\
\hline Lower-income & $\begin{array}{l}0.027 \\
(0.77)\end{array}$ & $\begin{array}{c}0.051^{* *} \\
(2.1)\end{array}$ & $\begin{array}{l}-2.5 \\
(-1.3)\end{array}$ & $\begin{array}{c}-1.5 \\
(-0.94)\end{array}$ \\
\hline Male & $\begin{array}{c}-0.056^{*} \\
(-1.8)\end{array}$ & $\begin{array}{c}-0.0023 \\
(-0.11)\end{array}$ & $\begin{array}{l}-3.1^{*} \\
(-1.9)\end{array}$ & $\begin{array}{c}-0.56 \\
(-0.38)\end{array}$ \\
\hline White & $\begin{array}{c}0.080^{* *} \\
(2.2)\end{array}$ & $\begin{array}{l}0.005 \\
(0.17)\end{array}$ & $\begin{array}{c}-1.7 \\
(-0.77)\end{array}$ & $\begin{array}{c}-0.43 \\
(-0.21)\end{array}$ \\
\hline Age & $\begin{array}{c}-0.0002 \\
(-0.18)\end{array}$ & $\begin{array}{l}0.001 \\
(1.5)\end{array}$ & $\begin{array}{c}0.20^{* * *} \\
(3.6)\end{array}$ & $\begin{array}{c}0.15^{* * *} \\
(2.6)\end{array}$ \\
\hline High Numeracy & $\begin{array}{c}0.10^{* * *} \\
(2.7)\end{array}$ & $\begin{array}{c}-0.063^{* *} \\
(-2.5)\end{array}$ & $\begin{array}{l}-1.1 \\
(-0.62)\end{array}$ & $\begin{array}{l}-0.60 \\
(-0.37)\end{array}$ \\
\hline Has Child under Age 18 & $\begin{array}{c}0.030 \\
(0.73)\end{array}$ & $\begin{array}{c}0.0088 \\
(0.28)\end{array}$ & $\begin{array}{l}-4.0^{*} \\
(-1.9)\end{array}$ & $\begin{array}{c}-2.4 \\
(-1.3)\end{array}$ \\
\hline Has Child Age 14-17 & $\begin{array}{c}0.076 \\
(1.2)\end{array}$ & $\begin{array}{c}-0.052 \\
(-1.2)\end{array}$ & $\begin{array}{c}2.6 \\
(0.92)\end{array}$ & $\begin{array}{l}5.5^{*} \\
(1.8)\end{array}$ \\
\hline Local Area \% College-educated & $\begin{array}{c}0.004^{*} \\
(1.8)\end{array}$ & $\begin{array}{l}-0.001 \\
(-0.88)\end{array}$ & $\begin{array}{l}0.10 \\
(1.0)\end{array}$ & $\begin{array}{l}-0.016 \\
(-0.19)\end{array}$ \\
\hline Local Area Median Inc (000's) & $\begin{array}{l}-0.003^{* *} \\
(-20)\end{array}$ & $\begin{array}{l}0.001 \\
(16)\end{array}$ & $\begin{array}{l}-0.05 \\
(-0.82)\end{array}$ & $\begin{array}{c}0.002 \\
(0.040)\end{array}$ \\
\hline Local Area RCE & $\begin{array}{c}-0.0097 \\
(-0.24)\end{array}$ & $\begin{array}{l}0.042 \\
(1.6)\end{array}$ & $\begin{array}{c}-0.96 \\
(-0.43)\end{array}$ & $\begin{array}{c}0.57 \\
(0.29)\end{array}$ \\
\hline Flagship County & $\begin{array}{c}-0.067^{*} \\
(-1.9)\end{array}$ & $\begin{array}{l}0.017 \\
(0.68)\end{array}$ & $\begin{array}{l}-0.25 \\
(-0.12)\end{array}$ & $\begin{array}{l}-1.4 \\
(-0.79)\end{array}$ \\
\hline Elite University County & -0.055 & 0.011 & -3.0 & -2.4 \\
\hline Local Private Sticker Cost & $\begin{array}{l}-1.3) \\
0.003 \\
(1.1)\end{array}$ & $\begin{array}{l}(0.44) \\
-0.001 \\
(-0.93)\end{array}$ & $\begin{array}{c}(-1.6) \\
-0.12 \\
(-0.98)\end{array}$ & $\begin{array}{l}-1.13) \\
-0.11 \\
(-1.0)\end{array}$ \\
\hline Local Public Sticker Cost & $\begin{array}{c}-0.003 \\
(-0.53)\end{array}$ & $\begin{array}{c}-0.0006 \\
(-0.18)\end{array}$ & $\begin{array}{l}0.37 \\
(1.3)\end{array}$ & $\begin{array}{c}0.72^{* * * *} \\
(2.9)\end{array}$ \\
\hline Constant & $\begin{array}{c}1.6^{* * * *} \\
(8.9)\end{array}$ & $\begin{array}{c}0.29^{* *} \\
(2.6)\end{array}$ & $\begin{array}{c}23.8^{* * * *} \\
(3.1)\end{array}$ & $\begin{array}{c}5.8 \\
(0.73)\end{array}$ \\
\hline F-statistic ${ }^{b}$ & $2.5^{* * *}$ & $2.83^{* * *}$ & $2.5^{* * *}$ & $2.2^{* * *}$ \\
\hline & 0.041 & 0.049 & 0.043 & 0.034 \\
\hline Number of Observations & 1096 & 1096 & 1093 & 1085 \\
\hline Mean of Dep. Var. & 1.6 & 0.41 & 30 & 23 \\
\hline
\end{tabular}

Weighted OLS estimates of a regression of the dependent variable on various controls
Robust standard errors in parentheses. $*, * * * * *$ denote significance at the 10,5 , and $1 \%$ levels, respectively.

${ }^{a}$ Relative College Earnings (RCE) is the ratio of the average earnings of 40-year-olds with a college degree to that of those without a college degree.

${ }^{b}$ F-statistic of a test of the joint significance of the covariates. 
Table A3: Heterogeneity in Baseline Self Beliefs

\begin{tabular}{|c|c|c|c|c|c|c|c|c|}
\hline \multirow[t]{2}{*}{ Dependent variable: } & \multicolumn{4}{|c|}{$\overline{\text { Own Child's Attendance }}^{a}$} & \multicolumn{4}{|c|}{ 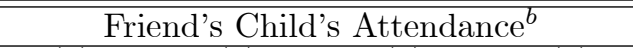 } \\
\hline & (1) & $(2)$ & $(3)$ & (4) & $(5)$ & (6) & (7) & $(8)$ \\
\hline Own Child's RCE ${ }^{c}$ & & & $\begin{array}{l}4.26 \\
(1.6)\end{array}$ & $\begin{array}{l}3.20 \\
(1.0)\end{array}$ & & & & \\
\hline Friend's Child's RCE & & & & & & & $\begin{array}{c}16.4^{* * *} \\
(5.6)\end{array}$ & $\begin{array}{c}15.4^{* * *} \\
(4.5)\end{array}$ \\
\hline Own Child's College Cost & & & $\begin{array}{c}0.16^{* *} \\
(2.3)\end{array}$ & $\begin{array}{l}0.13 \\
(1.6)\end{array}$ & & & & \\
\hline Population RCE & & $\begin{array}{c}6.12^{*} \\
(1.8)\end{array}$ & & $\begin{array}{c}3.66 \\
(0.83)\end{array}$ & & $\begin{array}{c}9.02^{* * *} \\
(3.4)\end{array}$ & & $\begin{array}{c}1.59 \\
(0.44)\end{array}$ \\
\hline Pop. Public Net Cost & & $\begin{array}{l}0.010 \\
(1.4)\end{array}$ & & $\begin{array}{l}0.039 \\
(0.45)\end{array}$ & & $\begin{array}{c}0.0060 \\
(0.11)\end{array}$ & & $\begin{array}{l}-0.014 \\
(-0.22)\end{array}$ \\
\hline Non-college & $\begin{array}{l}-4.54 \\
(-1.5)\end{array}$ & $\begin{array}{c}-5.08^{*} \\
(-1.8)\end{array}$ & $\begin{array}{l}-3.03 \\
(-1.0)\end{array}$ & $\begin{array}{l}-4.20 \\
(-1.5)\end{array}$ & $\begin{array}{c}-7.44^{* * *} \\
(-3.9)\end{array}$ & $\begin{array}{c}-6.79^{* * * *} \\
(-3.6)\end{array}$ & $\begin{array}{c}-4.99 * * \\
(-2.3)\end{array}$ & $\begin{array}{c}-5.23^{* *} \\
(-2.4)\end{array}$ \\
\hline Lower-income & $\begin{array}{c}-11.3^{* * *} * \\
(-2.9)\end{array}$ & $\begin{array}{c}-11.2^{* * *} \\
(-2.8)\end{array}$ & $\begin{array}{c}-11.7^{* * *} \\
(-3.0)\end{array}$ & $\begin{array}{c}-11.4^{* * *} \\
(-2.9)\end{array}$ & $\begin{array}{c}-6.75^{* * *} \\
(-3.0)\end{array}$ & $\begin{array}{c}-7.40^{* * * *} \\
(-3.3)\end{array}$ & $\begin{array}{c}-9.64^{* * *} \\
(-3.8)\end{array}$ & $\begin{array}{c}-9.61^{* * *} \\
(-3.7)\end{array}$ \\
\hline Male & $\begin{array}{l}-3.74 \\
(-1.1)\end{array}$ & $\begin{array}{l}-4.49 \\
(-1.3)\end{array}$ & $\begin{array}{l}-3.07 \\
(-0.87)\end{array}$ & $\begin{array}{l}-3.96 \\
(-1.1)\end{array}$ & $\begin{array}{c}-3.80^{*} \\
(-1.8)\end{array}$ & $\begin{array}{c}-4.48^{* *} \\
(-2.1)\end{array}$ & $\begin{array}{l}-1.69 \\
(-0.67)\end{array}$ & $\begin{array}{c}-2.45 \\
(-0.97)\end{array}$ \\
\hline White & $\begin{array}{c}-7.26^{*} \\
(-1.8)\end{array}$ & $\begin{array}{c}-8.78^{* *} \\
(-2.1)\end{array}$ & $\begin{array}{l}-7.14^{*} \\
(-1.78)\end{array}$ & $\begin{array}{c}-8.68^{* *} \\
(-2.1)\end{array}$ & $\begin{array}{c}-0.20 \\
(-0.07)\end{array}$ & $\begin{array}{c}-0.27 \\
(-0.10)\end{array}$ & $\begin{array}{c}0.80 \\
(0.22)\end{array}$ & $\begin{array}{c}1.13 \\
(0.31)\end{array}$ \\
\hline Age & $\begin{array}{c}0.0005 \\
(0.0)\end{array}$ & $\begin{array}{c}-0.0043 \\
(-0.02)\end{array}$ & $\begin{array}{l}-0.022 \\
(-0.10)\end{array}$ & $\begin{array}{l}-0.030 \\
(-0.13)\end{array}$ & $\begin{array}{l}0.021 \\
(0.26)\end{array}$ & $\begin{array}{c}0.050 \\
(0.62)\end{array}$ & $\begin{array}{l}0.034 \\
(0.41)\end{array}$ & $\begin{array}{l}0.057 \\
(0.68)\end{array}$ \\
\hline High Numeracy & $\begin{array}{l}5.50 \\
(1.4)\end{array}$ & $7.00^{*}$ & 6.42 & $\begin{array}{l}7.43^{*} \\
(1.9)\end{array}$ & $6.46^{* *}$ & $\begin{array}{c}7.04^{* * *} \\
(2.8)\end{array}$ & $\begin{array}{l}7.07^{* *} * \\
(23)\end{array}$ & $\begin{array}{l}7.70^{* *} \\
(2.5)\end{array}$ \\
\hline Has Child under Age 18 & & & & & $\begin{array}{l}4.52 \\
(1.6)\end{array}$ & $\begin{array}{l}4.07 \\
(1.4)\end{array}$ & & \\
\hline Has Child Age 14-17 & $\begin{array}{l}2.05 \\
(0.48)\end{array}$ & $\begin{array}{c}1.62 \\
(0.38)\end{array}$ & $\begin{array}{c}2.36 \\
(0.58)\end{array}$ & $\begin{array}{c}2.73 \\
(0.65)\end{array}$ & $\begin{array}{c}9.03^{* * *} \\
(2.8)\end{array}$ & $\begin{array}{c}8.24^{* *} \\
(2.5)\end{array}$ & & \\
\hline Local \% College-educated & $\begin{array}{c}-0.41^{*} \\
(-1.8)\end{array}$ & $\begin{array}{c}-0.47^{*} \\
(-1.9)\end{array}$ & $\begin{array}{c}-0.40^{*} \\
(-1.7)\end{array}$ & $\begin{array}{c}-0.48^{*} \\
(-1.9)\end{array}$ & $\begin{array}{c}0.26^{* *} \\
(2.0)\end{array}$ & $\begin{array}{l}0.21 \\
(1.6)\end{array}$ & $\begin{array}{c}0.34^{* *} \\
(2.5)\end{array}$ & $\begin{array}{c}0.32^{* *} \\
(2.3)\end{array}$ \\
\hline Local Med. Income (000's) & $\begin{array}{l}0.24^{*} \\
(1.9)\end{array}$ & $\begin{array}{c}0.26^{* *} \\
(2.0)\end{array}$ & $\begin{array}{c}0.22^{*} \\
(1.7)\end{array}$ & $\begin{array}{c}0.25^{*} \\
(1.9)\end{array}$ & $\begin{array}{c}-0.083 \\
(-1.0)\end{array}$ & $\begin{array}{l}-0.070 \\
(-0.85)\end{array}$ & $\begin{array}{c}-0.17^{*} \\
(-1.9)\end{array}$ & $\begin{array}{c}-0.17^{*} \\
(-1.8)\end{array}$ \\
\hline Local Area RCE & $\begin{array}{l}6.47 \\
(1.5)\end{array}$ & $\begin{array}{l}7.50 \\
(1.6)\end{array}$ & $\begin{array}{l}5.34 \\
(1.2)\end{array}$ & $\begin{array}{l}6.71 \\
(1.4)\end{array}$ & $\begin{array}{c}-2.17 \\
(-0.83)\end{array}$ & $\begin{array}{l}-1.73 \\
(-0.66)\end{array}$ & $\begin{array}{l}-2.31 \\
(-0.74)\end{array}$ & $\begin{array}{l}-2.046 \\
(-0.66)\end{array}$ \\
\hline Flagship County & $\begin{array}{c}8.55^{* *} \\
(2.3)\end{array}$ & $\begin{array}{c}8.96^{* *} \\
(2.3)\end{array}$ & $\begin{array}{c}8.84^{* *} \\
(2.4)\end{array}$ & $\begin{array}{c}9.06^{* * *} \\
(2.3)\end{array}$ & $\begin{array}{c}0.29 \\
(0.10)\end{array}$ & $\begin{array}{c}1.04 \\
(0.36)\end{array}$ & $\begin{array}{c}-0.79 \\
(-0.23)\end{array}$ & $\begin{array}{c}-0.75 \\
(-0.21)\end{array}$ \\
\hline Elite University County & $\begin{array}{l}5.12 \\
(1.2)\end{array}$ & $\begin{array}{l}5.81 \\
(1.3)\end{array}$ & $\begin{array}{l}5.15 \\
(1.2)\end{array}$ & $\begin{array}{l}5.47 \\
(1.3)\end{array}$ & $\begin{array}{l}-1.11 \\
(-0.40)\end{array}$ & $\begin{array}{c}-1.61 \\
(-0.59)\end{array}$ & $\begin{array}{l}1.40 \\
(0.45)\end{array}$ & $\begin{array}{c}0.82 \\
(0.26)\end{array}$ \\
\hline Local Private Uni Sticker Cost & $-0.45^{*}$ & $-0.43^{*}$ & $-0.46^{* *}$ & $-0.44^{*}$ & -0.027 & -0.0085 & -0.047 & 0.0013 \\
\hline Local Public Uni Sticker Cost & $\begin{array}{l}-0.67 \\
-0.67 \\
(-1.2)\end{array}$ & $\begin{array}{l}(-1.9) \\
-0.74 \\
(-1.3)\end{array}$ & $\begin{array}{l}(-2.0) \\
-0.65 \\
(-1.2)\end{array}$ & $\begin{array}{l}(-2.0) \\
-0.70 \\
(-1.3)\end{array}$ & $\begin{array}{c}(-0.15) \\
-0.42 \\
(-1.2)\end{array}$ & $\begin{array}{c}(-0.05) \\
-0.40 \\
(-1.1)\end{array}$ & $\begin{array}{c}(-0.22) \\
-0.36 \\
(-0.88)\end{array}$ & $\begin{array}{l}-0.35 \\
(-0.84)\end{array}$ \\
\hline Constant & $\begin{array}{c}105.3^{* * *} \\
(7.6)\end{array}$ & $\begin{array}{c}93.2^{* * *} \\
(5.9)\end{array}$ & $\begin{array}{c}97.1^{* * *} \\
(6.4)\end{array}$ & $\begin{array}{c}91.7^{* * *} \\
(5.7)\end{array}$ & $\begin{array}{c}89.3^{* * *} \\
(8.0)\end{array}$ & $\begin{array}{c}72.5^{* * *} * \\
(6.1)\end{array}$ & $\begin{array}{c}64.8^{* * *} \\
(4.9)\end{array}$ & $\begin{array}{c}60.6^{* * *} \\
(4.3)\end{array}$ \\
\hline F-statistic ${ }^{d}$ & $2.5^{* * *}$ & $2.7^{* * *}$ & $2.6^{* * *}$ & $2.7 * * *$ & $5.5^{* * *}$ & $5.9 * * *$ & $6.6^{* * *}$ & $6.3^{* * *}$ \\
\hline $\mathrm{R}^{2}$ & 0.185 & 0.211 & 0.211 & 0.224 & 0.114 & 0.14 & 0.18 & 0.181 \\
\hline Number of Observations & 308 & 305 & 307 & 305 & 1107 & 1079 & 792 & 772 \\
\hline Mean of Dep. Var. & 80 & 80 & 80 & 80 & 81 & 82 & 80 & 80 \\
\hline
\end{tabular}

Weighted OLS estimates of a regression of dependent variable on various controls.

Robust standard errors in parentheses. $* * *, * * *$ denote significance at the 10,5 , and $1 \%$ levels, respectively.

$a$ The expected likelihood with which a respondent's child will attend college.

$b$ The expected likelihood with which a respondent would recommend college for a friend's 15-year-old child.

${ }^{c}$ Relative College Earnings (RCE) is the ratio of the average earnings of 40-year-olds with a college degree to that of those without a college degree.

${ }^{d}$ F-statistic of a test of the joint significance of the covariates. 
Table A4: Heterogeneity in Immediate Experimental Impacts

\begin{tabular}{|c|c|c|}
\hline Dependent variable: & $\begin{array}{l}\text { Own Child's } \\
\text { Attendance }^{a}\end{array}$ & $\begin{array}{l}\text { Friend's Child's } \\
\text { Attendance } \\
\end{array}$ \\
\hline & (1) & $(2)$ \\
\hline $\begin{array}{l}\text { RCE Experiment } \\
\ldots \times \text { x High Income \& College }\end{array}$ & $3.01^{* *}$ & $\begin{array}{c}1.64^{* * *} \\
(044)\end{array}$ \\
\hline ... x Low Income \& College & $\begin{array}{l}4.08^{*} \\
(2.4)\end{array}$ & $\begin{array}{c}0.55 \\
(0.54)\end{array}$ \\
\hline ... x High Income \& Non-College & $\begin{array}{l}1.87 \\
(1.6)\end{array}$ & $\begin{array}{l}1.25^{*} \\
(0.68)\end{array}$ \\
\hline .. x Low Income \& Non-College & $\begin{array}{c}8.53^{* * *} \\
(2.9)\end{array}$ & $\begin{array}{c}3.33^{* * *} \\
(0.91)\end{array}$ \\
\hline $\begin{array}{l}\text { Cost Experiment } \\
\ldots \times \text { x High Income \& College }\end{array}$ & -0.31 & 0.35 \\
\hline ... x Low Income \& College & -1.93 & -0.16 \\
\hline ... x High Income \& Non-College & $\begin{array}{l}(2.6) \\
-0.54 \\
(2.5)\end{array}$ & $\begin{array}{l}(0.67) \\
-0.27 \\
(0.55)\end{array}$ \\
\hline$\ldots \times$ Low Income \& Non-College & $\begin{array}{r}-4.67 \\
(3.4)\end{array}$ & $\begin{array}{l}(0.0) \\
0.19 \\
(0.71)\end{array}$ \\
\hline Constant & $\begin{array}{l}-20.61^{* * * *} \\
(6.1)\end{array}$ & $\begin{array}{c}-2.82^{*} \\
(1.6)\end{array}$ \\
\hline Demographics & Yes & Yes \\
\hline F-statistic ${ }^{c}$ & $1.8^{* *}$ & $1.6^{* *}$ \\
\hline $\mathrm{R}^{2}$ & 0.256 & 0.089 \\
\hline Number of Observations & 307 & 1084 \\
\hline Mean of Dep. Var. & 1.4 & 0.84 \\
\hline
\end{tabular}

Weighted OLS estimates of a regression of the dependent variable on various interacted controls. Robust standard errors in parentheses. ${ }^{*} * *, * * *$ denote significance at the 10,5 , and $1 \%$ levels, respectively.

$a$ The expected likelihood with which a respondent's child will attend college.

${ }^{b}$ The expected likelihood with which a respondent would recommend college for a friend's 15-year-old child.

${ }^{c}$ F-statistic of a joint test of the significance of the covariates. 


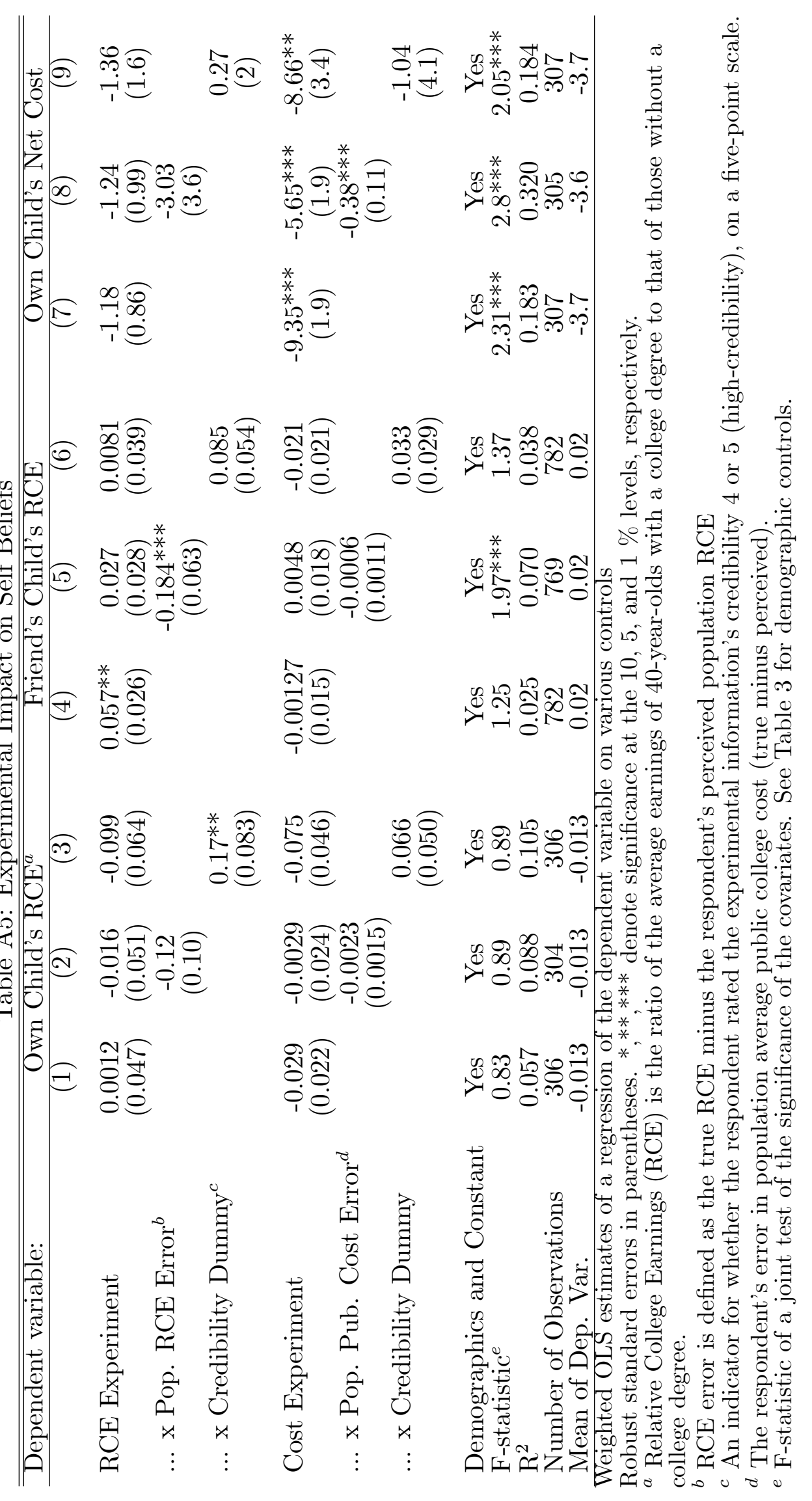

